腫瘍ウイルス の形態上芀類

\begin{tabular}{cccc}
\multicolumn{3}{c}{ 岡山大学平木内科（指導 : 平木潔教接 } \\
平 & 木 & & 潔 \\
太 & 田 & 善 & 介 \\
入 & 野 & 昭 & 三 \\
三 & 好 & 勇 & 夫 \\
瀬 & 崎 & 達 & 雄 \\
原 & 田 & 英 & 雄 \\
鈴 & 木 & 信 & 也 \\
大 & 里 & 尚 & 司 \\
永 & 森 & 俤一 郎 \\
守 & 屋 & 純 一 郎 \\
六 & 車 & 昌 & 士 \\
高 & 杉 & & 潔 \\
䭾 場 & 崎 & & 浩 \\
池 & 田 & 一 & 彦
\end{tabular}

[昭和 40 年 5 月 8 日受稿〕

I. 緒 言

II. B 型粒子群

1） マウス乳癌ウイルス

a. ウイルス粒子の形態分布

b. ウイルス粒子の形成様式

c. ウイルス粒子の negative staining 像

d. Bittner egent とその精製

e. 乳癌憡発系マウスの MTV

f. ウイルス粒子の生体内分布

g. 細胞移植によるウイルス量の変化

h. 組織培意

III. C 型粒子群

1) マウス白血病ウイルス

a. ウイルス粒子の形態，分布，形成様式

b. 非腫場性細胞内におけるウイルスの増殖

c. ウイルス粒子の negative staining 像

d. 白血病ウイルスの感染径路

e. 組織培養

f. C58 乳癌およびその組蟣培郎

g. X線および 20-methylcholanthrene 誘発
次

RF 白血病

h. 20-methylcholanthrene 誘発 RF 皮店癌

i. RF 自然発生肺癌

2）二ワトリロイコーゼウイルス群

a. ウイルス粒子の形態, 分布, 形成様式

b. ウイルス粒子の negative staining 像

c. 非腫場性細胞よりのウイルス粒子の形成

d. ウイルス粒子の宿主俵存変異

3) Rous 肉腫ウイルス

a. ウイルス粒子の形態, 分布, 形成様式

b. ウイルス粒子の negative staining 像

IV. A 型粒子群

V. D 型粒子群
1) Shope 乳頭腫ウイルス
2) ヒト乳頭畽ウイルス
3） ポリオーマウイルス
4) $\mathrm{SV}_{40}$
5）アデノウイルス

VI. $\mathrm{E}$ 型粒子群

1）伝染性㳄属腫ウイルス 
2) Shope 線維腫ウイルス

VI. F 型粒于群

1) Lucké 等癌ウイルス

\section{I. 緒言}

腫富ウイルスに関する研劣は古く，Ellermann ら の家哭自白血病, Rous らの家鶏肉腫等の研尖のよう に今世紀初めに溯ることが出来るが, 飛羁的発展の 基碄となつたのは Gross（1951 年）のア!ウス白血病 よりのウイルスの証明であると云えよう.

一方イルス粒子の電顕的観察はすでに1930年代 に試みられてはいるが, ウイルス粒子の詳細な形態 が明かにされるようになつたのは Palade の固定法 (1951年) による超薄切㸝法の紹介と, Horne らの negative staining 法 (1959年) に負うところが大き W.

以来，知られているはとんどすべての厙場ウイル スに関して極めて多数の氅顕的研呪が発表されて,

腫韵ウイルスは明確に形態学的に把握され, 絊胞内 増殖様式が明かにされ，腫湯細胞との cell-virus relationship が考察されるようになつた。

乳癌ウィルスの例の様に正確な定量法の知られて いないウイルスに関しては，電顕によるウイルスの 㹬明法が広く利用されているとと，あるいはヒト昰 悱腫瘍等のウイルス悱腫瑒の疑いのあるものでは先 ず電顐的にウイルス精子が近求されているととなど は腫晹ウイルスの研究における電顕的方法の重要吽: を物語つており，非腫瘍性ウイルスにおいてウイル スが分離された後電顕的に研究されるのとは対照的 である。

形態学的見地からはすでに Bernhard 13)14), Dmochowski51)，Howatson 106) らの総説，あるいは 2,3 の成帛 36)205）等が公にされているが分類はマウス腫 場ウイルスに止るあのが多いので，本文では既知の

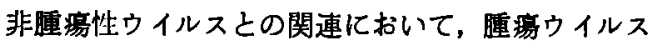
の形態，增殖様式等を通臨して一般的分類を試み， あわせて我々の実験成績を述へててない.

\section{B 型粒子群}

マウスの乳癌ウイルス (MTV) により代表される ウイルス粒子群である.

1) マウス乳漓ウイルス

a. ウイルス粒.子の形態, 分布

自然発生 $\mathrm{C}_{3} \mathrm{H}$ 乳癌組織では Bernhard 13)14)16)の
Vill. ヒト悪㺫腫楁に認りられたウイルス様粒子

XI. 総 括

X. 結 語

分類に従うと B 型および $\mathrm{A}$ 型の 2 種類のウイルス粒 子が認められる。

B 型粒子（写真 1）は細胞外，すなわち乳腺腺腔 内, 乳癌細胞の細胞間隙, および癌細胞の細胞兵空 胞内（空胞内は多くの場合細胞外と考えてよい）に 存在し，超薄切片上楕円形であり，その長径は锶察 者により多少の差はあるが，ほほ $100 \sim 120 \mathrm{~m} \mu$ 程度 である．粒子の中心部には扁在性に，オスミウム酸 に浱く固定される円形の核様体 (nucleoid) が存在し， その直径は約 $40 \mathrm{~m} \mu$ である．核様体以外のウイルス 粒子の部分すなわちウィロプラズム（viroplasm） にはよく撮れた強拡大の写真14)169）(写真1，4，5） ではウイルス粒子の最外層を含めて，3層の濃い膜 構造を認めることが出来る.ウイルス粒子は一般に はその大きさ，構造が均一であると云えるのである が, 腺檫内ウイルス粒子にはこれらの点について かなりのばらつきが見られ，核様体を 2 個有するも の（写真 5 )，ウイロプラズムが著しく膨化したも の等が見られ，この内には变性した粒子もあると思 われる.

$\mathrm{A}$ 型粒子一般については後述するが， $\mathrm{C}_{3} \mathrm{H}$ 乳癌ウ イルスに見られる $\mathbf{A}$ 型粘子（写真 2 ）は細胞質内特 にゴルジ野附近に集団的に存任し，巨大な封入体を 形成する，粒子は円型むしくは楕円形，一部 $\mathrm{C}$ 字型 等の未完成状態の粒子す見られ，中心部に核様体は なく, 内外 2 層の膜構造のみが認められる. 内層は やや厚く，電子密度加高いとされている，長径約 $70 \mathrm{~m} \mu . \mathrm{B}$ 型粒子は成熱ウイルス粒子であり, Bittner agent に一政する感染料子であることは今日ほほ定 説であるが，A型粒子がB型粒子の未熟型であると 云う説には若汗の異論がある。

b. ウイルス粒子の形成様式

MTV の形成様式に関する説は大別して 2 分され る.その一つは Bernhard 13) 14), 鈴木 202), 今井(31), 松井 169）らにより主張される説で，A型粒子は末整 ウイルス粒子であり，細胞表面で $\mathrm{B}$ 型粒子になると 云う。すなわちゴルジ野附近に存在する、リボソー ム類似の微細顆粒よりなるマトリックス（matrix） 内に A 型粒子が形成せられ， $\mathbf{A}$ 型粒子はその部分に 封入体を形成すると共に濑次細胞内を移動し，种胞 表面, microvilli の尖端等に達し，粒子の表面に細胞 


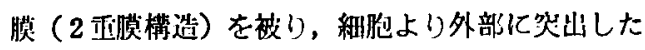
後，B型粒子となつて遊踓する (budding, shedding) (写真 1, 5). 少数のA 型粒子は細胞質内の空胞面に 達し，この部分で空胞面内に budding を行なう. 遊離前では中央部に核様体は認められず，粒子は内 部の A 型料子の 2 重膜構造と，その外部の細胞由来 の 2 重膜で，計 4 層の膜構進が観察されるが，（写 真 4) 遊離した後には極めて早い時期に最内層の膜 構造の内部の電了密度が増加して，核様体が形成さ れる.

Lasfargues, Moore，天野らはこれに対してA型粒 子はB型粒子の末熟型ではないと云う。天野ら山は SL 乳癌においてはA型粒子は存俚せず $\mathbf{B}$ 型粒子の みが観察されると述べ, Lasfargues 141)，Moore 162) らは A 型粒子は存在するが， B 型粒子の数に比へてて 㥛めて少ない場合のあること，細胞質内特に細胞膜 直下にA型粒子を認めることが少ないとと, A型粒子 が比較的多数集まる癌細胞内の空胞膜面において B 型粒子の形成を見ることが少ない等の理由により前 説に対して否定的見解を述べている. 最近 Howatson 106) むB型粒子の大多数は細胞表面において 超電顕 的成分より形成されると云う意見を述へている.

以上 2 つの異つた MTV 形成の仮説を結論に導く 充分な成績は未だないが，若干の考察を試みること にする，一般に，A型粒子の形態を示す粒子は現在 までのところ畽滧組織又は腫瘍ウイルスに関係があ ると考えられる組織以外には認められておらず31), A 型粒子がウイルスに関係の深いものであることは 超薄切片上の形態からすうかがわれるが, negative staining においてもウイルス粒子に類似する構造を 示している(184). A，B両粒子は特別の場合72) を除い て殆んど常に共存し，Feldman70）によれば DBA マ ウスにおいては生後 6 ケ月以後, 又は妊娠すること により乳腺内に両粒子が同時に出現すると云う。従 つて両粒子は極めて密接な関係のあるととが判る。 又A 型粒子かs細胞膜上で B 型粒子中に取り入れられ るとすると, budding 中のウイルス粒子の内部に見 られる A 型粒子と細胞内部にみられる A 型粒子は形 热的に同一でなりればならないか，今井ら132）によ る上両者は形態的に差異がなく，それぞれ半月状， C 字型, 円形のA 型粒子が認められて，その数も互 に相関すると云う。

これらの事実より $\mathbf{A}$ 型粒子は細胞の反応産物，他 種ウイルス等と考えるより，B型粒子の前段階と考 えた方が妥当のように思われる、ただインフルエン
ザウイルスに抽ける不完全ウイルスのように細胞内 に形成さ机たウイルス粒子の奖材がすべて成熟ウイ ルス粒子に取り込まれるとは限らず，過剩のウイル ス吽:蛋们がウイルス栐構造として琶められる可能性 のあるととも考虑しておく必要がある. $\mathbf{A}$ 型粒子の 抗原性，核酸の有無，感染性等の追求加望まれる。

A 型粒子を未熟型として認めるが否かは別として， B 型粒子が細胞表面で細胞膜の budding により形 战されることは確認された事実とみてよい，螢光抗 体法によつても細胞膜附近に一致してウイルス抗原 が観察されている116) 162). 同様のウイルス粒子の形 成様式はインフルエンザウイルスで見られ160), 又架 胞内に budding により形成される過程は我々が訨: 明した日本脳炎ウイルス 179) 183) や西部ウマ脳脊髄 炎ウイルス 158) 等のアルボウイルスでも観察されて いる.

同一細胞内でウイルス粒子が別の形成様式に彷つ て作られるととは考えにくいが，Moore16) は細胞質 基䝯内で B 型粈子が形成されることがあると速べて いる. A 型粒子の形成過程についても異説があり, 木下ら 137) は Dalton 39) らがマウスの形梖細胞腫に おいて観察したように滑面小胞体の一部が細胞質内 は突出することより $\mathbf{A}$ 型粒子が形成されるとしてい る.これらはいずれも確認された説ではない.

c. ウイルス精子の negative staining 像 negative staining による乳癌ウイルス粒子の観察 はすでに Moore 163), Dmochowski 59), Parsons 184), Howatson 106) らにより行なわれている. B 型精子 （写真 3）は直径 130 160 m $\mu$ の円形粒子として観 察され，その表面より長さ約 $10 \mathrm{~m} \mu$ の規則定しく配 列した梀状突起 (spine, knob, spicule, fringe, spike) が突出する，粒子の中央部には超薄切片上の核様体 に一致する円形の構造がみられ，外周には膜構造の 䜑められることもある. このようなウイルス粒子の envelope (表面膜) の構造はインフルエンザウイル ス粒子のそれに 105) 酷似するための MTVはミクソ ウイルス群に分類されるのであるが，MTV ではイ ンフルエンザウイルス粒子に見られるような内部の 螺線状構造は未だ証明されていない。

negative staining 上B型粒子は時に尾部を有す るように見られることがあるが，これは希釈液中の 塩類の濃度による影響であると云う的。

超薄切片上では通常棘状突起は明瞭でないが，固 定の極めて良好な写真では前述のB 型粒子の3 層 構造の最外層 加笑起の配列として見られる 14)65). 
(写真 4 ).

一般に negative staining 像は超薄切片に比へてて ウイルス粒子の直径がやや大きい，粒子の扁平化， 乾爆条件等の影響であろう。

A 型粒子は negative staining では直径 $70 \mathrm{~m} \mu$ の ドーナツ型構造として観察され，その表面には点状 構造の配列が見られる 106) (184)。

以上 $\mathrm{C}_{3} \mathrm{H}$ マウスの自然発生乳癌ウイルスについ てその形態，形成様式等について述へたが DBA70), $\mathrm{DBA} / 212^{277)} \mathrm{R}$ 핑) 我々の報告した AKR 103)(181) 等 の乳癌 (写真 4, 5, 6) 飞おいても同様のA，B両 型のウイルス粒子および budding による形成様式 が証明されている。

d. Bittner agent とその精製

次に電顕上みられるいずれの䊀子が Bittner agent であるかと云う問題であるがウウイルスを大量に集 める方法, 正確な定量法等が未だ確立されていない 現在断定的な結論は出ていない. Moore 164)165)の物 理学的方法を応用した実験, Dmochowski ら 60) の milk extract の観察等により，B型粒子が Bittner agent すなわち感染性のある完全ウイルス粒子であ ろうと考えられている。

なお MTV の精製法を 2，3挙げておくと，Fluorocarbon を用いる方法 200)，電気泳動を利用する方 法(65)，密度勾配遠心法 (199)204)，によるあの等が拨告 されている.

e. 乳癌嫌発系マウスの MTV

MTV は $\mathrm{C}_{3} \mathrm{H}, \mathrm{DBA}, \mathrm{R}$ III型等の乳㿋好発系化 いてよく研究されたのであるが，その後乳癌様発系 あしくは bioassay により MTV が存在しないとさ れている $\mathrm{C}_{3} \mathrm{Hf}$, 19)189) $\mathrm{Af} / \mathrm{Dm}, \mathrm{C}_{3} \mathrm{HZb} / \mathrm{Bi} / \mathrm{Dm}^{204)}$ お よび我々の報告した $\mathbf{A K R}$ 等についても，その乳 癌, hyperplastic alveolar node 等に電顕的に, 同様 のウイルス粒子が証明されることが判明した．との ことは MTV の発癌性に対する未解決の問題を提出 していたか，最近 Dmochowski 51) は virus-free と 考えられるマウス $\left(\mathrm{C}_{3} \mathrm{Hf} / \mathrm{He}, \mathrm{Ax}\right)$ ，の乳癌組織又 は乳汁中に電顕的にウィルス粒子を証明し，かつそ の extract は発瘚能のあることを証明している。こ れはマウス乳癌には従来考えられている以上に広く Bittner agcnt が関与していることを示していると 思われる。

又 hyperplastic alveolar node に多数のウイルス 粒子が存在するととは170)180) MTV が発癌に関して 重要な役割を演じていることを示すと同時に，細胞
の癌化と云う立場から見ると先ず組縰内でウイルス が增殖し，ある期间を経た後細胞が㺕化すると云う two-step theory が成立することになる (Moore)162)。

f. ウイルス粒子の生体内分布

MTV の生体内分布については bioassay 或いは電 顕的に多少研究さ机ているが 711622219)，MTV の起 源は乳癌組織であり，他の膕器で証明される場合に は，乳癌より遊出したウイルスが血行に入つたため であると考えられている. 我々の行なつた螢光抗 体法による研究もてれらによく一致した成績を示 す115).

g. 細胞移植によるウイルス量の変化

細胞移植により癌組織内に見られるウイルス粒子 が量的にどのように変化するかと云うことは癌細胞 の悪性度の維持にウイルスが必要であるかどうかに 関連して興味がある. Feldman 72) は DBA 乳癌組 織を細胞継代するに従いウイルス粒子の減少を認め ており，先ず B型粒子が消失し， $\mathrm{A}$ 型粒子は 45 代に 及んで証明出来ることを報告している。

我々も先きに述へた AKR 乳癌を in vivo 亿細 胞継代しており，最初の 4 代まで $\mathrm{A} ， \mathrm{~B}$ 両型ウィル スが初代と同程度に観察されたが，5代でやや減少 し， 8 代で A， B両型粒子共約半数となり，21代以 後では細胞外にドーナツ型をしたウイルス粒子（不 完全ウイルス粒子?）を認めるのみとなつた（写真 7). bioassay による研究であ細胞秚代に従いウィ ルス量が減少すると云う報告が多い21112)。

h. 組織培養

正常の堵益細胞を用いて MTV を増殖させる実験 は Lasfargue日ら 142) が報告しており，回転培益で正 常の乳腺を培養し，MTV を接種し，1ケ月でと にその遠心上清を bioa㔭ay したところ3ケ月まで 照性であつたと云う結果を得ている. 乳癌組織そ のものを培蓝する実験では同じく Lasfargnesら 141) はRIIIの自然発生乳癌の初代培羚を行ない，10 12 日までウイルス粒子を電䫓的に証明しており，Sanford ら 194) は $\mathrm{C}_{3} \mathrm{H}$ 乳疮組䄳の長期培羙で 6 ケ月か ら 1 年以上に亘つてウイルスの活性を認めている. その他 Sykes ら 2093), Howatson ら 110) む同棣の実 験を行なつている，我々の行なつた $\mathrm{AKR}$ 乳癌の組 織培養の結果は後述する.

以上 MTV の形態を中心にしてそれに関係した研 究結果について述べたが，B型粒子群䎲入るウイ スは現在までのととろ MTV のみのようである. 、 ウス白血病に B 型粒子を認めると云う記载もおる16) 
があまり正確な観察とは思えない，A型粒子は多数 の腫漡組織て観察されており，とれについては後に 述へる.

\section{C 型粒子群}

マウス白血病ウイルスによつて代表されるウイル ス群である．C型粒子はマウスでは Friend 白血病， Moloney 白血病, Gross 白血病, Rauscher 白血病, Graffi 白血病，SL 白血病等のほとんどすべての白 血病において観察される. Graffi 白血病のウィルス 粒子はB 型粒子であろうと云う記栈もある16)。 ニワ トリロイコーゼ群ウイルス, Rous 肉腫ウイルス等 はウイルス粒子の形態としては，むしろB型粒子に 属すると思われるが，発生過程等をす考慮して一応 この群に入れる。

1) マウス白血病ウイルス

a. ウイルス粒子の形態，分布，形成様式

通常 C 型粒子が認めら机ることが多いが， C 型粒 子が細胞膜上で形成される時，一時的にA 型粒子の 形態を示す. C 型粒子（写真 8) は細胞外すなわち

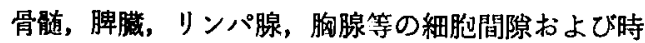
に白血病細胞内の空胞中に認められ, 又その臟器の 網内系細胞に多数䟺喰されている像をも観察するこ 之が出来る.

超薄切片上棈円形で長径活ぼ 80 100 $\mu$ m, Dalton ら38)は白血病の種類により $100 \mathrm{~m} \mu$ の粒子と, $90 \mathrm{~m} \mu$ の粒子との $2 つ の$ 群に大別出来ると云う．前者には Moloney 白血病, Manaker-60 (Schwarz) 白血病, 後者には Gross 白血病, Friend 白血病, AKR 白 血病等のウイルス柆子が属する，粒子の中心部には 電子密度中等度の棈円形の核様体が同心状に存保し， その長径は約 $60 \mathrm{~m} \mu$, 内部に点状又は管状の構造が 見られる場合もある．核様体の外部にはほ之んど無 構造のウィロプラズムが存在し, 最外層は 2 重の膜 構造より成る. ウイルス粒子の大きさ, 構造にはか なりの差異が見られることがあり，我々の観察した $\mathrm{C}_{58}$ 自然発生白血病 181)では粒子の著しく臌化した もの, あるいは眼綰したもの等の変性像か認められ た.

ウイルス粒子は白血病細胞の膜面上より，MTV 之同様細胞膜の budding により形成されることが de Harven ら 41243) により示されて以来追試, 確認 された.ウイルス粒子が未だ細胞表面に細管状の pedicel (写真15) により附着している閒はウイルス 粒子中央の核様体は形成されず，粒子は一見 2 重膜
構造として観察され， $\mathrm{A}$ 型精子の形態を示す． 細胞 内部には未熟ウイルス粒子を諗めることは出来ない， ただ稀にA型粒子に類似した構造を細胞内に認めた 例がある38)。このような増殖様式は非腫湯性ウイル スとしては既述のようにインフルエンザウイルスに 見ら机ている。

以上の白血病ウィルスの形態，形成過程は Friend 向血病 41)43354)139) Moloney 白血病 3438) Graffi 白血 病788) Gross 白血病 17784), SL 白血病 129), Rauscher

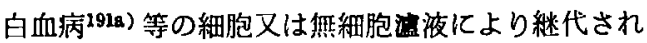
ている白血病ウイルスでも，AKR 7)1838534)， $\mathrm{C}_{3} \mathrm{H} /$ $\mathrm{Fg} / \mathrm{Lw}{ }^{38)}, \mathrm{C}_{58}$ 181) 等 の自然発生白血病にみられる ウイルスです，又我々の泼告した RF X線 133）又は 20-methylcholanthrene 117) 誘発白血病に観察される ウイルスでもほほ同様の結果を示している。

ウイルス粒子の特種な形態として cylindrical form が存在するととが報告されている（AKR白血 病(99)、Moloney 白血病37338) . Dalton ${ }^{37)}$ は Moloney agent により惹起したマウスおよびラットの脾およ び骨䯣の巨核球内に通常のウイルス粒子に等しい直 径を有する，2 重膜構造より成る円柱状のウイルス 粒子を認めている. 我々あ後述の $\mathrm{C}_{58}$ 乳癌で核様体 のある cylindrical form のウイルスを観察した. 球形のウイルス粒子が時として円柱状になることは インフルエンザウイルス160), ポリオーマウイルス107) 等であ知られており，インフルエンザウイルスでは 円柱状の粒子は感染性がないとも云われている. 正 確な意義は不明である。

又この円柱状のウイルス柆子に関連して，通常の budding とはやや異つたウイルス粒子の形成過程を Lalton らは述へている 37 )。すなお，円柱に数個 のくびれが生じ，その各部が球形のウイルス粒子と なると云う仮説である. 分離する直前の球形のウイ ルス粒子はおのおの紐状の bridge によつて連続さ れており，じゅず状配列を形成している．類のない ウィルス粒子の形成様式である．日本脸炎ウィルス において我々も類似の像を認めたととはあるが，形 成過程に対する考えが罢つている183)。

ウイルス粒子の素材が細胞内のどの部分で形成さ れるかについては定説がない，天野らはSL 白血病 の電䫓ならびに螢光抗体法による所見を基礎にして， 堭場ウイルスの細胞表層形成説6)を説えた。すすなわ ちゥイルス抗原は白血病細胞の細胞表面又は細胞膜 直下のみに観察され，従つて細胞のごく表層のみが ウィルス増殖に関与し，細胞犋の内部，核等は哭関 
係であるよ云う。このこよはウイルスの塔殖と細胞 の代謝が同一緗胞において背作するに適した状態で あり，腫晹ウイルスに特杕なものである之将えてい る.しかしなかららこれに対する反証も多い，教至小 场らの行なつた $\mathrm{C}_{58}$ 自然発生白血病の螢光抗体法 に上る実験115)140)では細胞表面のみならず，核周等 にもウイルス抗原が詡められ，又 Rauscher 白血病 では核に大量のウイルス抗原が証明されている74)。

b. 非腪場性細胞内におけるウイルスの增殖

一般に腫瘍ウイルスは腫場細胞より形成されると 云うことが出来る.すなわちウイルス粒子のbudding を認める細胞は腫演細胞である．しかしこれは in vivoにおいても例外があり，興味ある問題を提川 している. 乳㵠の場合の hyperplastic alveolar node については既述した，白血病の場合は巨核球が白血 病ウイルス形成の埸となり得るととを前述のように， de Harven43), Dalton 3333438) らは留告している。 の場合巨核球は悪性化しているとは考えられない。 白血病の相類に上り巨核球中に認めら机ぬことがあ るが, Meloney 向留病, Friend 白血病ではウイル 粒子が多量に形成され，AKR 自然発生白血病で も認めることが临惊ると云う。 又 Feldman ら73)は Gross の Passage A ウイルスを注射した $\mathrm{C}_{3} \mathrm{H}$ (f) マウスの乳腺上皮細胞より白血病ウイルスが形成さ れることを穓察している．ての場合も上皮細胞は痁 化しているとは考えられていない，又頪似の例を二 ワトリロイコーゼウイルスであ見ることが山米る。 これらの例をみるとウイルスの增殖之緗胞の悪性化 と云うことは同時的の梘象でなく，分離して見わ れることがかなりあるととか判る.

c. ウイルス粒子の negative staining 像

ウ血病ウイルスの精製法には朱だ完全な力法が知 られていないか，ほぼ䊁製されたと考えられる材料 あるいは spread cell 法184) に上つて negative stainingによる観察が行なわれている。. Dalton ら36377) は Moloney 白血病のウイルス粒子を䚌察し，円形 のウイルス粒子のみならず， $\mathrm{T}_{2}$ ファージの上うに 尾部を有する粒子をも多数見出した．その頭部はほ ほ6 角形であつて，二の最小直径は $100 \sim 150 \mathrm{~m} \mu$, 尼部は艮さ約 $250 \mathrm{~m} \mu$ である. 尼部のあるウイルス 粒.子は超薄切片上においても観察することが出来, 特に巨核球にこのような柆子加多い，又彼等によれ ばA型類似の粒子より渐次尾部を有する粒子にまで 移行型を観察することが出来, 従つてウイルスの成 熟した最終の形態が尾部のあるウイルス粒子であり，
尼部は人工的商物ではなかろうと絬論している．尾 部のあるウイルス料丁は Okano ら178) む Gross 的

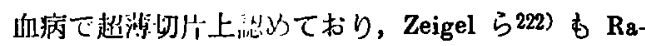
uscher 白血病ウイルスについて negative staining により証明している.

最近 de Harven ら44)は Friend 白血病マウスよ りヘパリン加生理的食塩水で血筤を分離すると, 精 㱔されてたウイルス柆子は全く円形であり，0.306 M のクエン䣨ンーダを用いると尼部のあるウイルス粒 子が多数現われてくる結果より尾部は人工的産物て あると結論している，又 Dmochowski ら 59）は用い

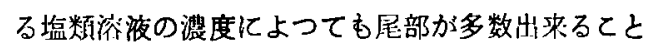
があると述へている，尼部はその長さ，形，出現頻 度等が比較的一定せぬ等のことより多くは人工的産 物上若えられる。

白血病ウイルス粒子の negative staining 像は乳 㿈に比へてて鮮明さを欠ぎ，その超微細構造は一般に うかがわれ谟い. Parsons ら 185) は Gross 白血病ウ イルスの negative staining で表面に乳癌ウイルス で見られるを同様の棘状突起を証明しており，粒 子の最表層はインフルエンザウイルス精子，乳癌ウ イルス柆子と同漛 envelope 上り成ると述へている が, エーテルで envelope を破買してもインフルエ ンザウイルスに見られるような内部の蝶線檕造は観 察し得なかつた。しかしながら Zeigel ら 223) は葆 溜水, 種々の浱度の食壏水で Rauscher 白血病のウ イルス粘子を破壊し明膫な表面の棘状突起のみなら ず, 内部の nucleopotein komplex の観察に成功して いる.これらの形態的特徴よりマウス白血病ウイル スはミクンゥイルス群に属すると考えられている。

d. 自血病ウイルスの感染経路

マウスの自然発生白血病の感染経路に関して, Gros8 81) は経町感染であることを推定したが，その 後 Law, Moloney ら143) Gross85) により経母乳感染, 又 Moloney ら 167) 井田ら 122) により経胎盤および 経母乳感染も証明された。これらに対する形態的裹 付けは比較的少ないが，Dmochow日ki ら59)は AKR の卵巣にウイルス粒子の budding 像を証明してお り, 又 $\mathrm{AKR}$ の胎児にも電顕的に未熟ウイルス粒 子を証明すると云う。一方先きにあ述へたように Feldman ら 73) は PassageA ウイルスの注射を受け たマウスの釈汁中に白血病ウイルスを電顕的に証明 しており，又井田，福原ら 130）も同様の所見を報告 している.

以上主に白血病好発系マウスについて白血病ウイ 


\section{腫晹ウイルス}

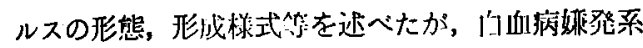
(RF) の自然発卡自血病にあウイルスが関与するこ とを我々は証明している97)。

e. 組織培祦

MTV と同様白血病ウイルスの組織埪榣法による 増殖実験む未だ十分成功したとは云えない，一般的 に或程度のウイルスの増殖は起るようである。

Manaker ら 151) は Moloney 白血病ウイルスは正 常マウス脾の初代培登に堌殖可能ですることを就告

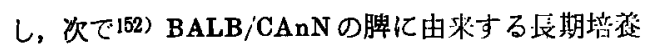
䚀胞はMoloney 白血病ウイルスに感受性があり,ウ イルスを接種後約 4 年にわたりウイルスを放出する 系を得，かつ leukemogenicity のあるととを証明 している. 最近 Peries188) は Rauscher ウイルスを 注射した BALB/C の腎組織を培養し，かなり長 期にわたつてウイルスが放出されることを見てい る.

本邦においては天野ら 175) が SL 白血病に由来す る白血病細胞の長期体外培盖に成功し， C 型粒子が 多数形成されることを電顕的に証明し, 又螢光抗体 法により細胞の表面およびウイルス粒子に一致した 部に特異螢光の存在することを証明しているが5)129) ウイルス粒子を含む培養液は leukem ogenicity が殁 んどないと報告している.

AKR 乳癌の組織淁蒦

我々は AKR 自然発俘乳痹に多数の A 型および B型粒子を電顕的に诓明し，てれらの精子は細胞移 殖により濑次減少していくことを先きに述へた，教

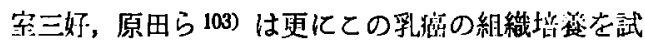
みて長期培湖成功し興味ある結果を得ている，細 胞移殖第, 4 代目の腫湯より得た初代坫盖 (419 strain cells）では期待に反して原発庫場に見られた $\mathrm{A}$ およ びB型粉子は殆んど証明するととが利来ず，白血病 ウイルスに酷似した 型粒子を細胞外に証明した。 このウイルス粒子は超溥切片上棈円形で，直径約 90 $\mathrm{m} \mu$, 中心部の電子密度中等度の核様体は直径約 56 $\mathrm{m} \mu$ であつた。 ウイルス粒子は in vitro の継代と 共に減少したが，21代においても少数なからら $\mathrm{C}$ 型粒 子を訨明した (写真 7 ). この初代 419 strain cells を AKRに戻し移植したところ， C 型粒子は観察す るととが出来ず，再度細胞内のA型粒子と細胞外に 多数のB型粒子を証明することが出来, この戻し移 植を出発点とした培養細細 (162 strain cells) にお いては初代，12代，17代の電顕的観察により再度A， B両型粒子は消失し，細胞外の $\mathrm{C}$ 型粒子のみを証明

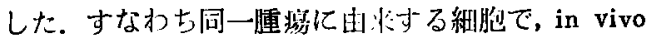
では常に A, B幽型粒于を, in vitroでは C 型粒子 を観察したわけである。てれは色々の説明が可能と 恐われるが，最初の乳徖に A 型およびB 型のウイル ス粒子のみならず，AKR が自然に保有する白血病 ウイルスが混仼し, in vivo, in vitro の差異によ りそのいずれかのウイルスの増殖が優勢になつたた めではなかろうかと推定している. bioassay による 研呪は实験中である．この样にマウスに由米する細 胞の組織培盗に目血病ウイルスが混往した例は他に ああり, Dales ら31)は Earle's strain L cell に白血 病ウイルスに類似した $\mathrm{C}$ 型粒子を証明しているが, leukemogenicity はないと云う，後述するようにポ リオーマウイルスの実験でも同様の現象が見られて いる.

f. C孚癌およびその組織培養

松井168) は SL 乳癌においてC 型粒子が存在する 例を報告しているが，教室鈴木ら 102）あ同様の例を 観察した。 $\mathrm{C}_{68}$ マウスにX線を全身一回350レントゲ ン照射したところ, 白血病発生は低下し，その内の 1例において乳癌の発生をみた。その組織内には電 顕的に A，B両型粒子は全く証明することが出来ず， 腺腔内に多数の C 型粒子を観察し，癌細胞表面によ りウイルス粒子が budding を行なう像を認めた(写 真 9). この細胞の in vivoの継代でも C 型粒子 (写真 10), および cylindrical form のウイルス

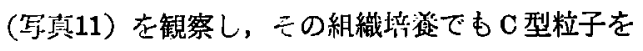
訶明している (写真 12).これらのウイルス粒子の bioassay は現代実験中である.このウイルス粒子は negative staining であ白血病ウイルスによく似， 直径約 $100 \mathrm{~m} \mu$, 円形の粒子として観察される（写 真13).

g. X線および 20-methylcholanthrene 誘発 $\mathrm{RF}$ 白血病

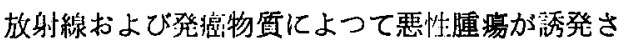
れることは古くより知られており，义一方ウイルス による発蹈も益々広い動物の筈囲にわたるととが最 近続々之証明されている. 従つて両者が発癌と云う 単一と考えられる現象を中心としてどのように関連 するかと云うことは重要なる問題であろう，Gross 82883), Dmochowski $ら$ 69) Lieberman $ら$ 145) Parson ら186)はX線により誘発した白血病にウイルスが関 与していることを無細胞演液接種実験あるいは電顕 的に証明しているが，教室入野ら120)133）白血病自

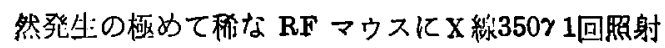


した後発生した白悉病マウスのリンパ腺等に電顕的 にウイルス柆子を証明し，又無細胞演液接種实験に も成功した。ウイルス粒子は細胞開隙に少炇存在し， ウイルス粒子は矢円形で直径約 $100 \mathrm{~m} \mu$ ，核様体は 直径 $70 \mathrm{~m} \mu, \mathrm{C}$ 型粒子に属し, 白血病細胞よりの budding 像を屯観察した (写真14).

化学物質による発癌にウイルスが関与するらしい ことを示唆する成績は Thiery ら210), Granboulan ら80)により報告されたが，白血病においては著者 等115a) 117) 119) 124) が 20-methylcholanthrene により 誘発した RF 白血病において最初に電顕的にゥイ ルスを証明し，又無細胞浟液接種実験でむ白血病 の発生を認めた。 そのウイルス粒子の形態, 形成様 式等は $\mathrm{X}$ 線誘発白血病の場合之ほとんど同様である (写真1.5, 16). その後木下ら 137)209) Toth ら211) らむ マウス白血病において同様の実験に成功している. このような実験成績から著者らは練胞内のマスクさ れたウイルスがX線又は化学物質により活生化され 細胞を癌化すると云う仮説を提案している ${ }^{116) .}$

h. 20-methylcholanthrene 誘発 RF 皮席癌

教室瀬㥓ら 118)は20-methylcholanthrene の0.5\% ベンジン溶液を RF マウス背部に長期塗布すること により高率化皮癌の発生を認めた。ウィルス粒子 は癌細胞の細胞問隙に認められ，梢円形で直径 100 $\mathbf{m} \mu$ ，核梯体は直径 $60 \mathrm{~m} \mu$ ，癌細胞表面より budding により形成される（写真17）。お书 Liebelt 144）む同 じ発癌物質で誘発したマウス肝蔵で類似のウイルス 粒子を証明している。

i. RF 自然発生肺癌

RF マゥスには桸に肺癌の自然発生を認めること が出来るが, この細胞は移植可能で, 組織内にウイ ルス粒子を電顕的に証明することが出来た181). 粒 子には 2 種類認められ，その一つは $\mathrm{C}$ 型粒子で, 前 述の RF マゥス厓膓に見られたウイルス粒子と形 態的には同一であり，細胞開隙に観察するととが出 米た (写真 18). 他の一種類の粘子は細胞質内ある いは細胞内空胞の近くに屡々見られる円形 2 重膜構 造で，直径約 $80 \mathrm{~m} \mu, \mathrm{A}$ 型粒子と考えられるるので ある (写真 19). 前述の C 型粒子と A 型粒子との関 係は明確にすることが出来なかつた。

2）二ワトリロイコーゼウィルス群

a. ウイルス粒子の形態, 分布, 形成様式

家跔の骨髄芽球症 (myeloblastosis), 赤芽球症 (erythroblastosis), リンパ球症 (lymphomatosis) を起すウイルスの一群である，Beard一派により詳
䚀に研究され、これらのウイルスは形態学的にも兔

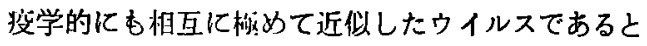
されている91).いずれのウイルス粒子す超薄切片上 ほほ円形で，直径約 $80 \mathrm{~m} \mu$, 中央には電子密度の高 い円形の核様体が存在し，その直径は約 $30 \mathrm{~m} \mu$, ウ イロプラズムにはウイルス柆子の最外層を含めて 3 層の摵い膜構造を認めることが出来る 14 ) (写真 20). このようなウイルス粒子の微細構造はマウス の白血病ウイルスよりもむしろ乳痹ウイルスに近い． ウイルス粒子は細胞外すなわち骨餚, 脾, リンパ腺 等の細胞間腺に見られるが, 骨骮芽球, 赤芽球, 細 網細胞等の空胞内に観察されることもある.

ウイルスの形成様式について早くより明かにされ たのは赤芽球症ウイルスであつてマウス白血病ウィ ルスの場合と同様, 赤芽球の細胞表面より budding により形成される (Benedetti ら10)，Iwakataら127)， Heine ら95)) (写真21). 細胞内には未熟ウィルス粒 子と思われるあのは確認されていない, budding 中 のウイルス粒子は一時 $\mathrm{A}$ 型粒子の形態をとる．

岩片 135）は螢光抗体法により赤芽球症のウイルス 抗原は細胞表面涀われる場合之細胞質内に現われ る場合のあることを示している。

骨髄芽球症については色々の議論がなされたが， 个日ほぼ細胞表面より budding により形成される ものと考えられている.すなわち Bonar, Beard ら 22)91) は骨䯣芽球症の家鴊の未梢血中の骨䯣芽球の 培養を行ない, 空胞および gray body 中にウイル ス粒子を観察し，後者は系粒体又は顆粒の変化した あのであつて, ウイルス形成の場であると考え, viroplast と命名した. その後 Zeigel221) により正常 の embryo および家劲の膵臓細胞表面よりウイル 又粒子が形成されることが明かにされ，更に骨髄芽 球症の strain として知られている BAI strain A avian tumor virus によつて惹起された nephroblastoma の細胞 89), 骨䯣芽球症の䏫腺汇認められる細 胞86)等よりウイルス粒子の budding 像が証明され， viroplast でのウイルス形成が疑われるに到つた. 一方その後前述の viroplast 中には colloidal gold の䊉子が取り込まれることが証明され96),従つて viroplast中のウイルス粒子の少くとも一部は細胞外起 源のもの，すなわち含喰されたものであることが明 かとなつた，骨髄芽球症ウイルスについても䋖胞内 末熟ウイルス粒子は証明されていないが，時にてれ と思われる構造 (viroplasm，が見られることを Heine ら 99）が郝告している。 
リンパ球症についてはあまり詳細な研究がないが， Dnochowski ら 56) は細網細胞と思われる 細胞飞多 数のウイルス粒子を含む封入体を証明し，かつ前述 の Zeigel 221) の証明した budding 像はリンパ球症 ウイルスであると云う.

b. ウイルス粒子の negative staining 像

Bonar ら 22) により精筡骨颌芽球ウイルス（BAI strain A）および赤芽球症ウイルス（strain R）の negative staining 像が報告されている. 両ウイルス 共ほほ同様の形態を示し, 円形, sperm形, crescent 形でマウス乳癌ウイルス, 白血病ウイルスに見られ たと同様表面の envelope より突出する多数の橉状 实起か観察されている. 超薄切片上では栜状哭起は 明かでいいのか普通であるが, Zeigel 221)はきれい な像を発表している, negative staining 像および超 薄切片上の所見を基礎にして Beard ら22)は図1の ようなニワトリロイコーゼウイルス粒子の構造を推 定している.

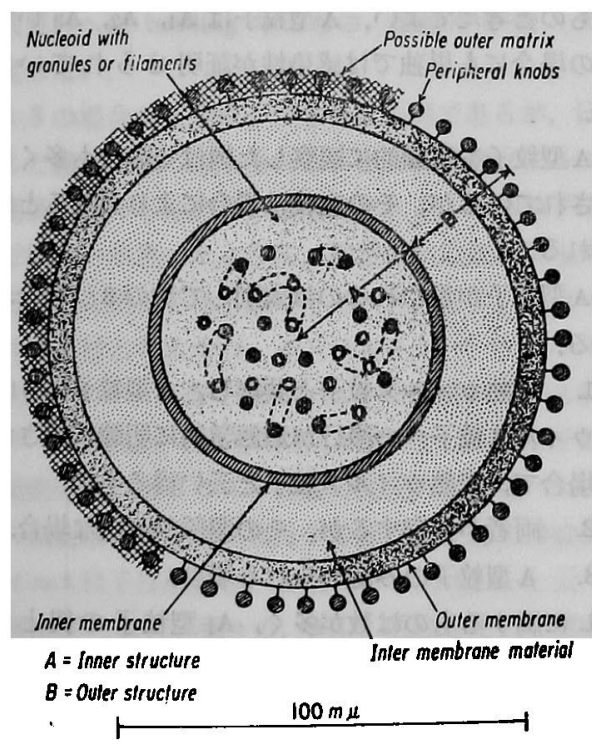

図1 ニワトリロイコーゼウイルス粒子の 構造（Beard 522)による）

c. 非腫湯性細胞よりのウイルス粒子の形成 マゥス白血病ウイルスにおいては腫汪細胞以外の 細胞功でもウイルス粒子が形成されることを述べ たが, ニワトリロイコーゼウイルスについても同様 の所見が涊められている．前述つ上うに Zeig el221) は正常の embryo お上び家呞つ㵏灌つ acinar cell よりウイルス粒子の budding を触察し, Heine ら 97) はBAI strain A ウィルスにより峞起された骨骮䔉，
球症においても同様の所見を諗め, 又 Guy de The ら 87)は hepatic lymphomatosis で細胆管に面した 肝実質細胞よりウイルス粒子の budding を証明し ている．てのような事実は腫湯性ウイルスの性質お よび細胞の癌化の過程を考える場合に重要な所見で あり, 又屎中にウイルス粒子が北, 悠染源になり得 ることを示している.

d. ウイルス粒子の宿主依存変貲

B型およびC 型ウイルス粒子は細胞膜の budding により形成されるので電顕的には細胞膜の一部がウ イルス粒子の表面磻を非成するように見える．従つ てウイルス粒子とその母細胞とは共通成分をむつて いるととが十分考えられる。

インフルエンザウイルスは細胞膜の budding に より形成されるが, 高度に精製されても宿主細胞の 抗原を含むととが沈降反応によつて証明されてい る138). strain A ウイルスむ同様宿主細胞の抗原を 含むことが Eckert ら 62) により証明されており， 更に Beard ら 88) は strain R ウイルスは家兔抗家 鶏組織血清でその感染能が中和されるととを証明し ている.

更に Heine ら99) は電顕的にもウイルス粒子が細 胞由来の成分を取り込む像を示している. BAI strain A ウイルスによつて生ずる nephroblastoma には chondrocyte, prechondrocyte が含まれており, これらの細胞よりウイルス粒子の budding が見ら れる. 正常の形態を有するウイルス粒子に加えて直 径約 $250 \mathrm{~m} \mu$ の大型のウイルス粒子 (globoid form, incompletely and aherrantly formed virus particle) が見られ，その内部には前記細胞よりウイルス粒子 と同時に形成されたと考えられる cartilage fibril が認められている. 我々あ前述した $\mathrm{C}_{58}$ 乳癌で $\mathrm{C}$ 型 粒子が母細胞より形成されたと考えられる構造を内 臟する像を観察している (写真 9 ).

骨䯣芽球症ウイルスは ATP ase を含むととが知 られているが, Guy de Thé ら 86) によれば ATP ase 活性は電顕的に宿主細胞およびウイルス粒子の表面 に証明され，ウイルス粒子の ATP ase は母細胞由 来のものであることが明かにされた. しかしながら 前述の nephroblastoma $の$ chondrocyte は ATP ase 陰性で，従つてての細胞より形成される骨䯣芽球症 ウイルス粒子は ATP ase 陰性になると云う88).

以上の諸事実よりウイルスは宿主依存変巽を受け 得ることがほぼ明からであろうと想われる。 
3) Rous 肉腫ウイルス

a. ウイルス粒子の形態，分布，形成様式 家鴙に生じた肉瘇 14)66)176）およひ，培養された chick embryo fibroblast $に$ Rous 肉建ウイルス (RS V）を感染させた材料 90）91)93）より，超薄切片法に より観察されたウイルス粒子の形態は前述のニワト リロイコーゼウイルスに殆んど一致し，ウイルス粒 子は細胞外又は細胞内の空胞中に認められる。 又 RSV に近緣の藤浪肉腫ウイルス粒子の形態もほぼ 同様である13)153)。

ウイルス粒子の形成過程について Haguenau91)は 細胞基兵内に認められるウイルス粒子の集合体より 成る gray body，义は時に同じく細胞内に集合性に 認められる直径 $40 \mathrm{~m} \mu$ の円胙粒子がウイルス粒子 の末熟形ではないかと述へているが，最近 Heine ら98）により RSV む肉隀沺胞の表面より budding により形成されることが明かとなつた。

b. ウイルス柆子の negative staining 像

RSV の negative staining に関しては Dourmashkin, Simons の詳細な研究がある48). 彼らによると ウイルス粒子は内部構造の明瞭なむの之, 不明睹な あのとの 2 種類があり，前者ではウイルス粒子の内 部には内外 2 層の膜構造および核様体が証明される。 ウイルス粒子の表面には乳癌ウイルス等に認められ たと同様の棘状㔖起が突出し，時にウイルス粒子の 内部化は六角形，結晶状配列の subunit が観察され る. ウイルス粒子の外形は多く多角形であるが，才 タマジャクシ (tadpole) 型のものも観察されてい る.

最近 Rubin ら (93)，花房ら94)，Shimizu ら 196)は Rous 肉腫ウイルスの Bryan 株には RSV と RAV (Rous-associated virus) の2種類のウイルスが混 在することを証明し，RSVは in vivoで肉埂を形 成し，培盖細胞の tranaformation を起すが, defective virus で, RSV のみでは完成されたウイルス粒 子を形成することが仙米ず, helper ウイルスとして の RAV の重複悠染を浔て後，初めて完全なウイル スとして細胞外敒出され，功つ helper ウイルス はニワトリロイコーゼウイルスと同じであると云う. この報告は細胞の唅化とウイルスの関係に重要な 問題を提出しているが，同時に花房113）の述へるよ うに Bryan 怢の大部分は RAV より成り，従つて Bryan 株を用いた実験はまにニワトリロイコーゼ ウイルスを観察していたここになる。

\section{A 型粒子群}

A 型柆子は Beruhard14)によりマウスの腫场ウイ ルス粒子の分類上命名されたもので，Dalton ${ }^{33) ， d e ~}$ Harven40) らにより詳細に研究されて $A_{1}, A_{2}$, $\mathbf{A}_{3}$, の subgroup に分類されている. de Harven に上れ ば $\mathbf{A}_{1}$ 型柆子は budding 中の白血病ウイルス, $\mathbf{A}_{2}$ 型粒子は乳癌ウイルス $\mathbf{A}$ 型粒子、 $\mathbf{A}_{3}$ 型粒子は budding 中の乳癌ウイルスによつて代表される。

A 型粒子は一般的に電子密度の高い膜構造により 成り，核様体を欠ぐ円形の粒子であるが，その構造 には種類により若干の差巽が見られ，焦点のよく合 つた強拡大の写真では $\mathbf{A}_{1}$ 型煜子は 3 重膜棈造を40)43) （写真15)， $A_{2}$ 型粒子は 2 重模構造を14）（写真 2,6）, A3 型煜子は 4 重膜構造14)を認める（写真1４）。

A 型粒子の中心部には成熟ウイルス粒子に認めら れる電子密度の高い核様体は存在せず，一見中空の 粒子に見える，従つておそらく完全な形の核酸はな いあの上考えてよい，A型粒子は $A_{1} ， A_{2} 、 A_{3}$ いず れの場合にも単独では惑染性が証明せられていな W.

A 型煜子を電顕的に観察した例はその後も多く報 告されているか，その意義は場合により異なると思 われる。

A 型粒子が見われるのは大別して次の 3 つ場合か ある。

1. 成然ウイルス粒子と共存し， $\mathbf{A}$ 型柆子より成 热ウイルス粒子への移行が形態学的に明瞭に示され た場合で，末熟ウイルス粒子と云い得るすの.

2. 両者が共存するが，その関係が不明な場合.

3. A型粒子のみ認められる場合.

1.に属するものは数が多く， $\mathbf{A}_{1}$ 型柆子の例とし ては Friend, Moloney 白血病ウイルスを初めとし て C 㷱粒子群として既述したマウス白血病ウイルス および我々の認めた乳㴼の C 型ウイルス粒子の未熟 形，すなわち膜面で budding 中の $\mathrm{C}$ 型粒子，およ びA3型粒广テの例としてマウス乳淊ウイルスの budding 中のB型粒户と，拉てらくニワトリロイコーゼ ウイルスのそれとがこれに入る. Moloney 白血病等 で観察された cylindrical form のウイルスすこれ に属する上考えられる。. cylindricol form は円形の 成熟ウイルス䊉-千になることもあるようであるか， 内部の核様体相当の棈造を涊めぬことが多いので， 大部分はそのままの北で睍察された部位に留り，脚 に不完全ウイルス粒子？よして細胞外に遊離するこ 
ともあるのではなかろうか. 前述のように我々は $\mathrm{C}_{58}$ 乳缩の移植腫劰で内部に核様体の明膫な cylindrical form のウイルスを認めたので, 円柱状の完 全ウイルスも存任するかる知れない。

2.には Earle’s strain L 細胞で認められた粒子31)， 我々の観察した RF 自然発生肺嵒ウイルス粒子お よび 1.であるとする説が多いが一応 $\mathrm{C}_{3} \mathrm{H}$ 乳癌等 の細胞質内のA 型粒子をここに挙げておく.

3. 任属するものも数が多く，Swiss マウスの transplantable ly mphoma40)42)，マウスの愿宣細胞腫(9) 109)，マウスの降傜28)，エストロゲンにより誘発さ れたマウスの Iymphoma(98)，BALB/C の testicular interstitial-cell tumor 187), Ehrlich ascites tumor cells 76) 220), methylcholanthrene 誘発マウス肉腫 ${ }^{16)}$ 80)，正常 $\mathrm{C}_{68} \mathrm{BL}$ の副睪丸の小胞体内 71) 等および SL 白血病に見られた伪ウイルス粒子128) であつて, その存任部位も細胞質基質内, 空胞内, 小胞体内, 細胞表面より budding 中のあの, 空胞膜より細胞 貢基質内へ逆 budding 中のあの, 細胞外等様 々で 一定しない.

2. 3 の場合のA 型粒子の意義は不明であるが，ほ とんと睡場組織に認められることから腫場ウイルス に関係の深いあのが多いと推定される. B型粒子の 項で既に一部述べたうに，細胞の反応産物等之考 えるより A 型粒子は未熟のウイルス，あるいはウイ ルスの装材と考えたい. インフルエンザウイルス 159a)，ポリオーマ等で忍められる不完全ウイルス粒 子30)等に㥵当するすのかるしれない，B 型粒子群 の細胞移植によるウイルス量の変化の項で述へたよ うに細胞継代を長期にわたつて続けると遂には成熟 ウイルス柆子は消失し， $\mathbf{A}$ 型粒子のみ残ると云う Feldman72) および我々の，AKR 乳通を用いた実験 成積はこの考えを支持していると思われる. 3. の場 合にはおそらくウイルス性核酸の合成障害が付随す るのであろう。 ウイルス性蛋白（および脂質）のみ が粒子を形成することは前述のインフルエンザの不 完全ウイルス粓于に明膫に見られる1159a).

\section{D 型粒子群}

PAPOVA ウイルス群および,ウイルスの群は巽 るか形慜ならびに形成梯式が頑似しているアデノウ イルスをD型柆子群に入れる。 PAPOYA ウイルス 毻は Melnick 166)により命名されたもので papilloma (Shope papilloma, human papilloma), polyoma, vacuolating $\left(\mathrm{SV}_{40}\right)$ ウイルスより成り，いずれす 2
本銷の DNA を有し，抚態学的にはとんど同一で， 核内增殖を示し, essential lipid を火ぎ, 造腫察泩 がある等の特微を示す。

1) Shope 乳頭腫ウイルス (Shope papilloma virus)

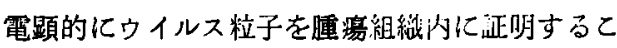
とはかなり因難であるが, Moore ら166), Stone ら 201)により初めてワタオノウサギ(cotton-tail rabbit) の組織队にウイルス粒子が訓明さ机た。 ウイルス粒 子は円形で直径 $33 \mathrm{~m} \mu$ ，電于密度の高い粒子として 観察されるが，その外部には膜構造が存任するらし (104). ウイルス粒子は腫䞍組織の上首である KeratInized cell 内に観察され, 先ずその核小体内に微 細顆粒状のマトリックスが現われ，次でその内部に ウイルス柆子か形成され，核内にひろがる.興味あ るととには隀壕組織の深部にある proliferating cell 中にはウイルス粒子が証明さ机難い，螢光抗体法に よつても同様のウイルス抗原の分布が証明されてい Ђ218).

ウイルス粒子は浱度勾配遠心法により容易に精製 され 25)218), 感染性のある full partiule より成る 層の上部, すなわち比重の小さい部分には蛋白膜の みから成ると考えられる, 感染性のない hollow par ticle が分離され, 又 cylindrical form の粒子も観 察されている.

negative staining ではウイルス粒子の表面に規則 让しい capsomere の配列が認められ, Melnick 156) によ机ばこの数は42, Breedis ら25)は60〜70, Mattern154)は92と云う. 最近 Howatson 万108)は㳩妙 な方法で, Shope 乳頭腫ウイルスおよびポリオーマ ウイルスの capsomere の数を数え, 再度 42 と主張 している. Crawford ら29)は Shope 乳頭腫ウイル ス, bovine papilloma ウイルス, canine papilloma ウイルス, human papilloma ウイルスのおのおのと ポリオーマウイルスの混合液を negative staining により観祭し，papilloma ウイルスはポリオーマウ イルスよりやや大きいことを战告している.

ウイルスより抽山された核睃に柋染址があること はタパコモザイクゥイルスにより最初䚺明されたが， 腫垞ウイルスについては伊藤 126)134）加初めて成功 した. 彼27)によると Shope 乳頭腫より得た DNA により生じたワタナノゥサギの乳頭腫中にも電頙的 に完全ウイルス柆子が泟明さ扎们る。

2) ヒト乳頭腫ウイルス (Human papilloma virus) 
ヒトの上皮（皮有および粘膜）細胞に虑染して乳 頭腫 (verrucae vulgares, wart; largngeal papilloma) を誘発する. Bunting26)により最初超薄切片法によ り乳頭腫内に証明された。

Williams ら3)217) によればウイルス粒子は乳頭盾 の granular layer の練胞の核内に認められ，円形 で直径 $46 \mathrm{~m} \mu$ ，核梯体之外膜より成る。時に核内に 結晶状の配列を作る。細胞質内には認められない. negative staining では円形柆子で42の capsomere が 観察される.

Dmochowski ら 61)によれば生検により得た laryngeal papilloma 中に認められるウイルス粒子は乳 頭腫内のウイルス粒子之形態学的に同じであり, ウ イルス粒子の直径は $36 \sim 44 \mathrm{~m} \mu$, 外膜および中心部 の核様体により成り，核様体の直径は 22 33m $\mu$ で ある. ウイルス粒子は乳頭腫の上層部の細胞の核内 に観察される.

3） ポリオーマウイルス (Polyoma virus)

腫湯組織 4755564)110)ならびに培養細胞 9558)110)(72) で超薄切片法により锶察された結果によると, ポリ オーマウイルスは円形, 洔に多角形で直径 $28 \sim 45$ $\mathbf{m} \mu$ ，薄い外膜 45) ならびに電子密度の高い核様体よ り成る. Bernhard(4) は外膜はなく, naked virusで あると云う. filament 状のウイルス粒子も証明さ れているが中心部は中空らしい45)(07), ウイルス粒 子は腫湯細胞又は感染細胞の核内で增殖し，無数の ウイルス粒子が認められ（写真 22）, 時に結晶状の 配列 1458)110)を示す. 細胞質内および細胞外にも同 様のウイルス粒子を認めることむあるが9172)，乙れ は細細胞破壊に伴う核膜の断裂のため粒子が核内よ り移钦したものであるらしい172). 従つてポリオー マウイルスは核内ですでに成熟ウイルス粒子となつ ているのである．培逢細胞の細胞質内にはこの他や や大きい, 㨁径 50〜60 m $\mu$ の粒子が認められるこ とがある 107) 172）が，これは細胞外に放出されたウ イルス粒子か，再度細胞内に取り込まれたものであ る45).しばしば細胞外には直径約 $100 \mathrm{~m} \mu$ のウイル ス粒子が観察されるが9661)，家兔抗ポリオーマ血清 により変化を受けないので. マウス白血病ウイルス の污染之考えられている15). Henle ら100), Malmgren ら150）に上り報告された螢光抗体法に上る研究も前 述の核内增殖を支持する.

Wildy ら216)によつて行な犼た negative stainingによる観察ではポリオーマゥイルスは平均直径 $44.7 \mathrm{~m} \mu$ ，正 20 画体で capsid は42の capsomere 上
り成る. 個々の capsomere は中空の正六角形柱ら しい. capsomere が超薄切片上に見られるウイルス 粒子の外膜に相当することは Bernhard の写真(6)を 見ればよく判る。

4) $\mathrm{SV}_{40}$ (Simian virus 40 )

アジア産のサル（rhesus）の腎培養組織中にしば しば混入してくるウイルスとして知られ。感染細胞 に特徽的な空胞状の変性を起すとてろから vacuolating agent とも云われる. Eddy63) Girardi ら79) に より初生児ハムスターに対して造腫淿性のあるとと が報告された。

Gaylord ら76)によればウイルス粒子の大きさは 約 $30 \mathrm{~m} \mu$ で．培金した猿の腎細胞では核内で増殖す る. negastive staining 156$) て ゙ 42 の$ capsomere が証明 される. O'coner ら 1777 あウイルス粒子の核内増殖 を電顕的に示している。

5）アデノゥイルス (Adenovirus)

アデノゥイルス粒于は超薄切片上円形で，直径約 60m $\mu$, 169) PAPOVA ウイルスよりやや大きいが. 核 様体之外膜より成り，核内で堌殖して，ウイルスの 型により核内で結晶を形成するものがあり，DNA 型で，増殖が遲い等の点でポリオーマゥイルスに類 似している. Trentin, Yabe, Taylor 212) によつて 12型が新生旧ハムスターに造䭪湯性のあるととが証 明され，次でHuebner ら111)によつて18型も造腫腸 性のあるととが報告された。発生した腫䕐からはウ イルスは分離出来ないと云う.

\section{VI. $\mathbf{E}$ 型粒子群}

Molluscum contagiosum, Shope fibroma のウイル スがこの群に入る.ウサギの myxoma ウイルスも前 2 者に類似のウイルスで共にポックスウイルス群に 入れられる。

1）伝染性㳄属属ウイルス（Molluscum contagiosum virus)

ヒト皮海の良性小腫湯であり，原因はウイルスと されている，腫場は深部より表層にかけて basal layer, spinous layer, granular layer, およひ最表 首の keratinous layer の4 層上り構成される40).

Banfield 5 8) Takakiら 208) Dourmashkin $ら$ 46) により電䫓的に研究さ机た。 Dourmashkin らによ ると basal layer にはウイルス粒子を認めないが, spinous layer より表層に到るに従つてウイルスの 形成過程を迫うことが出来, spinous 1.の細胞の細 胞啠内にみられる，顆柆物質の集合である viropla- 
sm 中に弧状の 2 重膜構造が現われ， viroplasmは 清次膜構造により包まれ，円形の粒子となる．この 円形粒子には核様体が認められるあのあある．円形 粒子の内部には次で変化が起り, 中空の 2 重膜構造 となる. granular 1. 亿は主にとの中空粒子（hotlow particle) 加封入体として認められる. keratinous 1. のウイルス粒子には更に内部構造の変化が起り, 中 心部に亜鈴状構造を持つ flattened particle となる. flattened p. 肪感染粒子と考えられ，その長径は 250 300 m $\mu$ である（図 2). この様なウイルスの 形態, 形成様式は非腫瘍性のポックスウイルスに極 めてよく似る32)101).

2) Shope 線維腫ウイルス (Shope fibroma virus) Bernhard ら (5), Lloyd ら 146), Febvre ら69) 等の 電顕的研究があるが, molluscum contagiosum ウイ ルスによく仙るので省略する．感染細胞におりるウ イルス抗原の分布, DNA 合成の部位については加 藤ら 136) の詳細な研究がある.

ウサギ伝染性粘液腫ウイルスについての電顕的観 察は新保 206) 加行なつている. 粒子の直径約 $300 \mathrm{~m} \mu$ と云う.

\section{F 型粒子群}

\section{1） Lucké 腎癌ウイルス}

現在ての群に入るすのには leopard frog に生ず る Lucké の renal adenocarcinoma ウイルスである. Fawcett68）により電顕的に詳細に研究された。 彼に よればウイルス粒子は円形で直径約 $100 \mathrm{~m} \mu$, 外膜は 2 重膜構造であるが，完全に困鎖されておらず，一 方汇穴があり，内部の核様体も穴の方へ扁在する. 核様体の直径は $40 \mathrm{~m} \mu$ ，ウイルス粒子は先す核内の

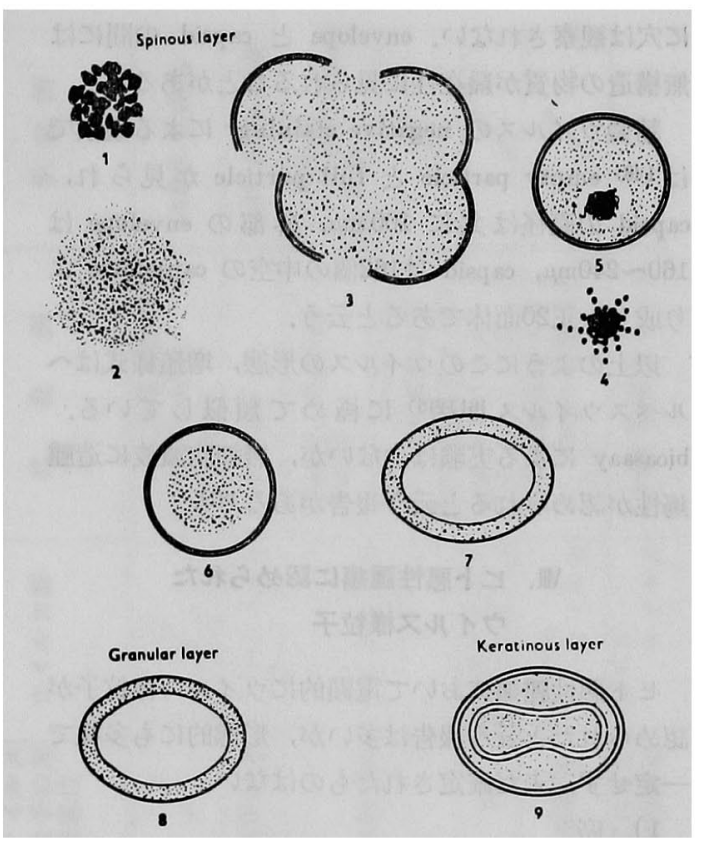

図2 伝染性㳄属腫ウイルスの形成過程

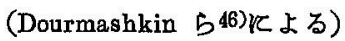

マトリックス中に現われ，円形の膜構造の内部にオ タマジャクシ形の dense spheroidal body が入つて 未熟ウイルス粒子が形成される. 未熟ウイルス粒子 は核内で成熟して上記成熟ウイルス粒子となり，細 胞質内に出，更に細胞膜より envelope を得て細胞 外江出る (図 3 ).

Lunger 147)148）によると envelope をるつた成熟粒 子は比校的少なく，細胞外（proximal convoluted tubule 又は細胞質空胞内）に認められ，超薄切片上 envelope を含めた粒子の直径は $200 \mathrm{~m} \mu$, capsid の 直径は $142 \mathrm{~m} \mu$ ，中心部の核様体は $75 \mathrm{~m} \mu$ で, capsid

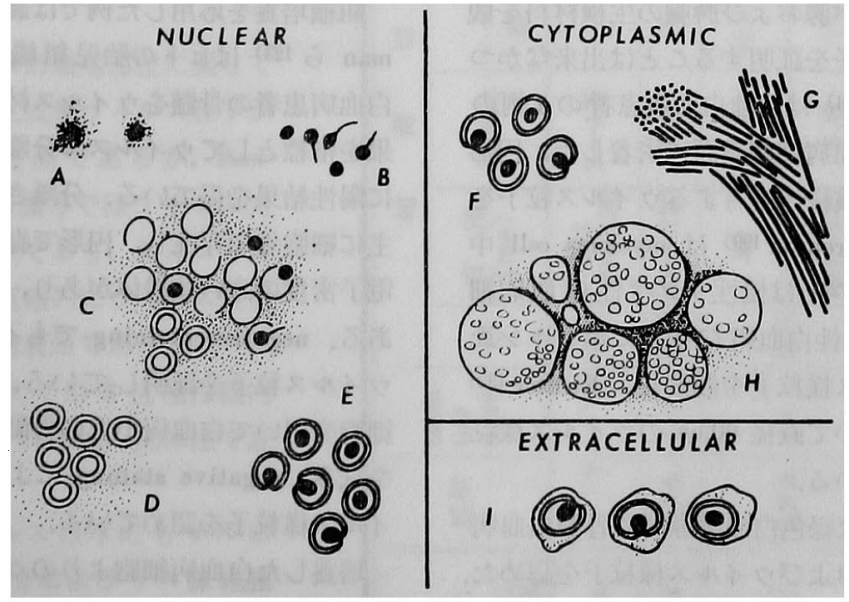

図 3 Lucke 留痹ウイルスの形成過程（Fawcett68）火よる) 
に究は観察されない. envelope と capsid の間には 無粠造の物質が扁任性に見られることがある.

精製ウイルスの negative staining による钼察で は 148) empty particle と full particle が見られ， capoid の直径は共に $100 \mathrm{~m} \mu$ ，外部の envelope は $160 \sim 240 \mathrm{~m} \mu$, capsid は162個の中空の capsomere 上 り成り，正20面体であると云う.

以上の上うにてのウイルスの形態，增细様式はへ ルペスウイルス 161) 215)に極めて類似している. bioasaay に上る然験は少ないか，然細胞流液に造腫 海性が忍められると云う战告がある191)。

\section{UII. ヒト悪性渪葛に認められた ウイルス様粒子}

ヒト悪性尰場において電顕的にウイルス様粒子が 認められたと云う哌告は多いが, 形態的にも多様で 一定せず，末だ確定されたものはない，

1) 婮

高小ら2M) 213) は胃傜, melanocarcinoma 等で直径 70 160 $\mathrm{m} \mu$ の膜構造を有するウイルス様柆子を認 わ, Haguenau 89990)はヒト乳癌の核内に微細顆柆より 成る封入体様構造および細胞質空胞内に A 型類似の 粒子を証明している. 又 Selicksou ら 195) あ Keratoacanthoma 中にウイルス様粒子を観察し叔告してい る等である。

2）白血病および肉腫

腫場組織を直接電䫓的に観察してウイルス様柆子 を見出した例として，Dmochowski 9950)51) はヒト白 血病患者のリンパ腺生検材料を襩察し，マウス白血 㑂ウイルスに類似した粒子を細胞間隙に認めてい るが, 迎試の成功例はない㥞である. 我々む多数の 白血病患者のリンパ腺および脾臓の生検材料を観 察したが，同梯の粒子を証明することは出来なかつ た. Braunsteiner ら 24) は急性白血病患者の1例の 骨髄細胞において白血病細胞表面に密着した，円形 の直径 75 95 $\mathrm{m} \mu$ ，核様体を有するウイルス精子を 戟明している. X Sorenson 199) は myeloma cell 中 K, Zucker-Franklin 224) (慢性リンパ性白血病細 胞内に，Besis ${ }^{20)}$ は急吽白血病ならゔにホジキン氏 病の細胞内にウイルス様恃子を観察し，Richter 192) むホジキン氏似において直径 $60 . n \mu$ のウイルス様煜 子の存在を叔告していふ。

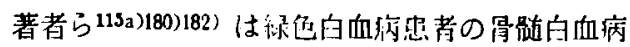

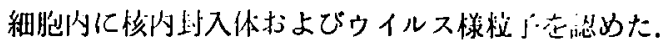

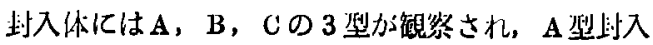

体（写真23）は直径約 $100 \mathrm{~A}^{\circ}$ の電子密度の高い微 細顆粒の集合より成り，B型封入体（写真24）はA 型よりも更に電子密度の高い顆粒の集合で，周囲は 電子密度の低い顆粒に上り取り囲まれている．B型 封入体は核小体内にも見られる。，型叔入体（写真 25）は無構造の物質の集合より成る粗大顆粒状構造 である．細胞澌内のゴルジ野附近には円形，㨁径 $100 \mathrm{~m} \mu, 2$ 重膜構造より成るゥイルス様柆子を稓察 した (写真26). A 型抢よび B 型封入体はゥイルス

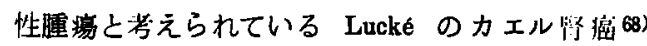

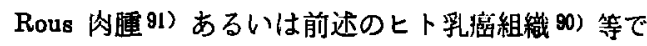
類似の構造が観察されており， C 型封入体は molluscum contagiosum ウイルス 46), ポリオーマウイル スの感染を受けたハムスターの腎107)等で認められ ている構造に似る. Хゴルジ野附近の円形構造はマ ウス釈癌等に見られる.A型粒子に極めてよく似て おりウイルス粒子ではないかと思われる。

末梢血を精製してウイルス粒子を証明しようよ云 う試みも行なわており, negative staining により Almeida ら2) が内部に核蛋白らしい蝶線構造を多 数もつた粒子を, Burger ら12) は直径 200 300 $\mathrm{m} \mu$ の尾部を有するウイルス様粒子を訨明している。 Porter ら 190) は negative staining によりやはり尼 部のある粒子を証明し，同柆子は pellet の超溥切 片で A 型柆子様の構造を示していることを証明して いるが，対照とした正常人 1 例でも同じ粒子が諰め られている. Benyesh-Melnick ら 11), Smith ら 197) む白血病患者, 伝染性単核症患者, および正常人よ り直径 90〜250 $\mathrm{m} \mu$, 膜構造を有するミクソウイル ス類似の粒子を negative staining により観察して いる.

組織培貝を応用した例では最近 Negroni171)，In-

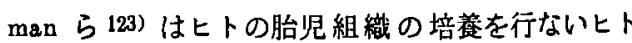
白血病患者の骨跹をウイルス材料とし，細胞变性勃 果を指植としてウイルスの分離を試み，25例中10例 に䧄性結果を得ている，分激されたウイルス粒子は 尘に細胞外に任位し，円形で直径 $73 \mathrm{~m} \mu$ ，中心部に 電千密度の高い核梯体があり，その直径は $42 \mathrm{~m} \mu$ て ある。 negative staining であ不明嘹なからら同様の

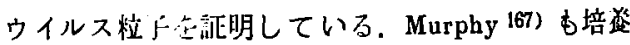
細胞を用いて白血病小児の骨䯣よりウイルスの分噰 を試子，negative stainngにより直径 $150 \mathrm{~m} \mu$ のウ イルス様柆子を贸めている。

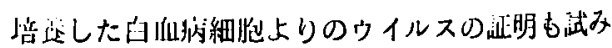
ら机ており，Graffi ら 78) 任自血岗望者の木悄血打 
よび骨䯣細胞を $2 \sim 6$ 日培善し, 核, 胞体 内に直径 $40 \sim 50 \mathrm{~m} \mu$ の電子密度の高い然棈 造の粒子を認め，又細胞膜より直径 60〜 $70 \mathrm{~m} \mu$ のウイルス粒子が budding を行なつ ている像を観察している. Iwakata ら 126) も白血病患者の白血病細胞を長期培篒し， 60日目に直径約 $110 \mathrm{~m} \mu$ のウイルス様柆子 を細胞外汇証明している. 又最近アフリカ で見出された Burkitt's lymphona の培商 湅胞内に Epstain ら67) はヘルペスウイル スに酷似した直径 110～115 m $\mu$ のウイル ス粘子を琎明している。

我々もヒ卜急性白血病蜆者の 1 例より得 た骨髄を培養し，6 日目に電顕的観察を試 みたところ Graffi らの㧐告するウイルス 様粒子に極めてよく似た，直径約 $30 \mathrm{~m} \mu$ の 電子密度の高い粒子を白血病細胞の細胞貢 内観察した，他の例についても追求中で ある.

なお Dmochowski 54)，Murphy 167) らは 白血病組織からは屡々 PPLO214) が分離さ れるので注意を要すると述へてている。

\section{XI. 総括}

以上述へた各群のウイルスの特徽を列挙 すると表 1 のようになる，A，B，C，D型 の命名は便宜上 Bernhard のマウス隀昜ウ イルスの分類を流用し， $\mathrm{E} ， \mathrm{~F}$ 型は新しく 加えた。 ウイルス粒子の形態および増殖樣 式を主な分類の根拠とし，核酸の種類は㚼 中144）に従つた。增殖様式をセーマで示す 上図4のようになる。

$\mathrm{B}$ 型， $\mathrm{C}$ 型ウイルスの增殖部位に関して は定説がない，電顕上成熟ウイルス粒子が 認められるのは細胞表面であるが，Rauscher 白血病, Rous肉尰竎ではウイルス抗

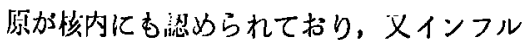
エンザウイルスでも電顕的にウイルス粒下 加認められるのは細胞表面であるが 160)，

Morgan ら 169a) K上りこの $\mathbf{S}$ 抗原は核内 で形成されるととが Ferritin 抗体法で証 明されている。

既述した腫場ウイルス以外にもサルの Yaba ウイルス腫, シカおよびリス湶維腫 等のポックスウイルス群比属するウイルス，

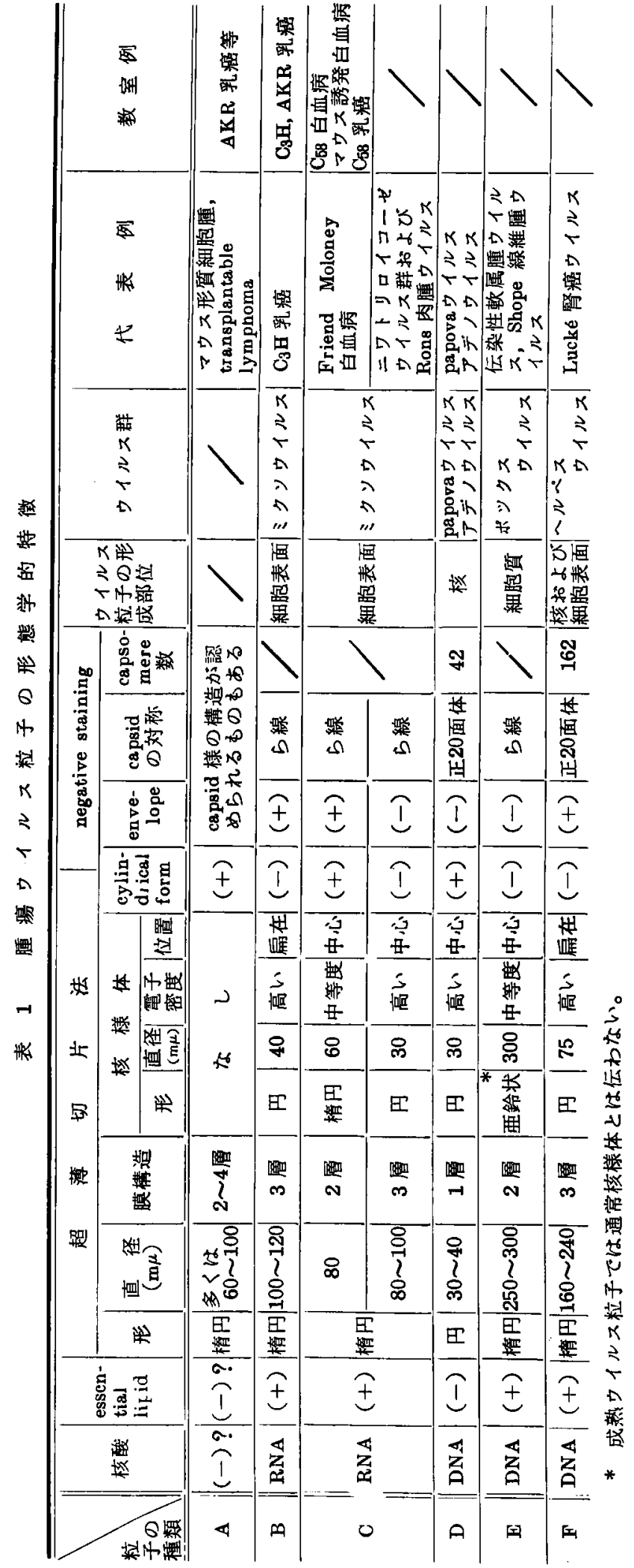




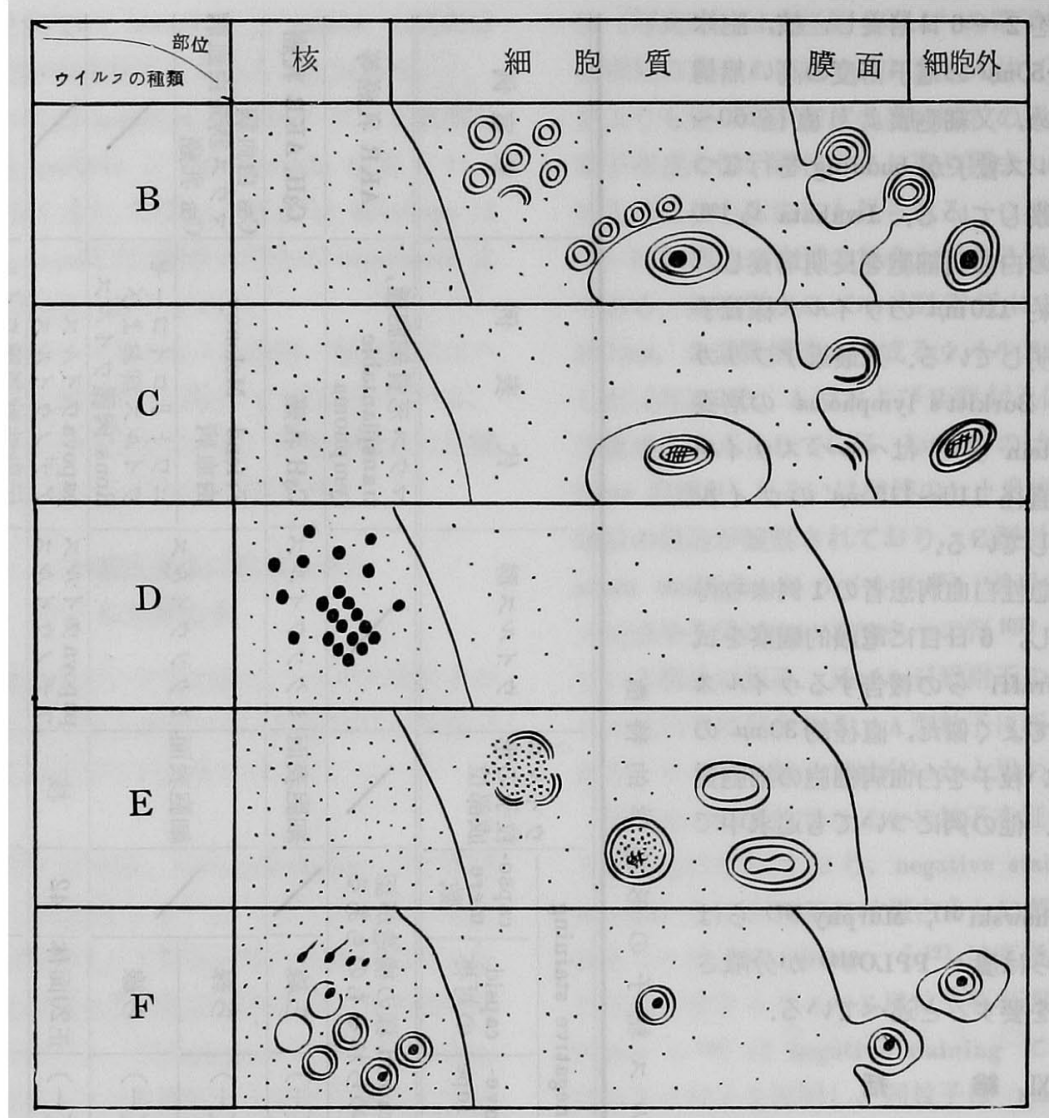

図 4 腫瘍ウイルス形成様式のそーマ

ラットの乳癌, 子宮癌等でゥイルス様粒子が認めら れているが形態的にあウイルス学的にも研究が少な いので省略した.

なおウイルスの大きい群を形成するピコルナおよ びアルボウイルス群では oncogenicity のあるウイ ルスが末だ知られていない。

最後に，今日迄に得られた電顕的研究の成果では 一応腫啺ウイルスと腫瘍形成とは密接な関係のある ことが示されたが，ウイルス性腫場における細胞の 悪性化，およびその持続の機構を電顕的に知るとと

文献

1) Ada, G. L. and Perry, B. T. : Infectivity and nucleic acid content of influenza virus. Nature 175:209-210, 1955.

2) Almeida, J. D., Hasselback, R. C. and Ham, A.W. : Virus-like particles in blood of two acute leukemia patients. Science $142: 1487$ $1489,1963$.
は出来なかつた。その機構はおそらく超電子顕微鏡 的レベルにあると思われ, mask されたウイルスあ るいはウイルス性核酸之細胞との微妙な関係にある のではなかろうか.

\section{X。結䇺}

現在までに知られている厙場ウイルスにつきその 形態, 形成式等を挙げ, 我々の得ている実験成績を 西記し，その分類を試みた。

3) Almeida, J. D., Howatson, A. F. and Williams, M. G. : Electron microscope study of human warts ; sites of virus production and nature of the inclusion bodies, J. Invest. Derm. 38 : 337-346, 1962.

4) Amano, $s:$ Ultracytological host-virus relationships in lenkemia and tumors of viral origin. 
Acta Haematol. Jap. 23 : 651-659, 1960.

5) Amano, S. and Ichikawa, Y. : Leukemic cells and etiological virus in long-term culture; their interrelationship with a considcration of the distribution of viral antigen. ibid. 25 : 695-702, 1962.

6) 天野重安：核と細胞澌との交流に関するウイル ス学的課題 細胞化学ンンポシウム11:23-37, 1961.

7）粟野亥佐武：癌ならびK白血病細胞の染色体と ウイルス. 㾌の臨床 $8: 191-201,1962$.

8) Banfield, W. G., Bunting, H., Strauss, M. J. and Melnick, J. L. : The morphology and development ef molluscum contagiosum from electron micrographs of thin sections. Exp. Cell Res. 3 : 373, 1952.

9) Banfield, W. G., Dawe, C. J. and Briudley, D. C. : Intracellular and extracellular particles in tissue cultures inoculated with parotid-tumor agent (polyoma virus). J. Nat. Cancer Inst. 28 : 1123-1135, 1959.

10) Benedetti, E. L. and Bernbard, W.: Recherches ultrastructurales sur la virus de la leucémie érythroblastique du poulet. J. Ultrastructure Res. $1: 309-336,1958$.

11) Benyesh-Melnick, M., Smith, K. O. and Fernbach, D. J. : Aseociation of myrovirus-like particles with acute leukaemia of childhood. Nature 202 : 1129-1130, 1964.

12) Burger, C. L., Harris, W. W., Anderson, N. G., Bartlett, T. W. and Kniseley, R. M. : Viruslike particles in human leukemic plasma. Proc. Soc. Exp. Biol. Med. 115 : 151-156, 1964.

13) Bernhard, W. : Electron microscopy of tumor cells and viruses. a review. Cancer Res. 18 : 491-509, 1958.

14) Bernhard, W. ; The detection and study of tumor viruses with the electron microscope. 20 : 712-726, 1960.

15) Bernhard, W., Baner, A., Harel, J. and Oberling, C.: Les formes intracytoplasmiques du virus fibromateux de Shope. ètude de coupes ultrafines au microscope électronique, Bull. Cancer $16: 423-444,1954$.

16) Bernhard, W. and Granboulan, N. : Morpho- logy of oncogenic and non-oncogenic mouse viruses. In: Ciba Foundation Symposium on tumor viruses of murine orgin, edited by $G$. E. W. Wolstenholme and M. O'connor, Little, Brown and Co., Boston, pp 6-55, 1962.

17) Bernhard, W. and Grost, L. : Présence de particules d'aspect virusal dans les tissus tumoraux de souris atteintes de leucémies induites. Compt. rend. acad. sci. $248: 160-163,1959$.

18) Bernhard, W. and Guérin, M. : Présence de particules tumoraux de souris atteintes de leucémie spontanée. ibid. $247: 1802-1805,1958$.

19) Rernhard, W., Guérin, M. and Oberling, C. : Mise en evidence de corpuscules d'aspect virusal dans différents souches de cancars mammaires de la souris. Acta Unino Internat. contra Cancrum, $12: 544-557,1956$.

20) Bessis, M. and Thiéry, J. P. : Étude au microscope électronique des hémosarcomes humains. III. leucémia a cellules-souches, erythrémies, reticulo-lympbo-sarcomes, maladie de Hodgkin, plasmacytoms. Nouv. Rev, Frane. Hématol. 2 : 577-601, 1962.

21) Bittner, J. J. : Assay of spontaneous and transplanted mammary tumors for the mammary tumor agent. Cancer Res. 13:361-366, 1953.

22) Bonar, R, A., Heine, U., Beard, D. and Beard, J.W. : Virus of avian myeloblastosis (BAI strainA). XXIII. morphology of virus and comparison with strain $R$ (erythroblastosis). J. Nat. Cancer Inst. 30: 949-997, 1963.

23) Bonar, R. A., Weinstein, D., Sommer, J. R., Beard, D. and Beard, J.W. : Virus of avian myeloblastosis. XVII. morphology of progressive virus-myeloblast interactions in vitro. NIC monograph No. 4, 251-290, 1960.

24) Braunsteiner, H., Felinger, K. and Pakesh, F. : On the occurrence of virus-like bodies in human leukema. Blood $15: 476-479,1960$.

25) Breedis, C., Berwick, L. and Anderson, T. F. : Fractionation of Shope papilloma virus in cesium chloride density gradients. Virology $17: 84-94,1962$, 
26) Bunting, H. : Close-packed array of viruslike particles within cells of a human skin papilloma. Proc. Soc. exp. Biol. N. Y. 84 : $327-329,1953$.

27) Chambers, V.C. and Ito, Y.: Morphology of Shope papilloma virus associated with nucleicacid-induced tumors of cottontail rabbits. Viro$\log y 23: 434-436,1964$,

28) Claude, A. : A spontaneous, transplantable renal carcinoma of the mouse. electron microscope study of the cells and of associated virus like particle. J. Ultrastructure Res. $6: 1-18,1962$

29) Crawford, L. V. and Crawfond, E. M. : A comparative study of polyoma and papilloma viruses. Virology $21: 258-263,1963$.

30) Crawford, L. V., Crawford, E. M. and Watson, D. H. : The physical characteristics of polyoma virus. I. two types of particle. ibid. $18: 170$ $-176,1962$.

31) Dales, S. and Howatson, A. F. : Virus-like particles in association with $\mathrm{L}$ strain cells. Cancer Res. 21 : 193-197, 1961.

32) Dales, S. and Siminovitch, L. : The development of vaccinia virus in Earle's $\mathrm{L}$ strain cells as examined by election microscopy. J. Biophys., Biochem. Cytol. $10: 475-503,1961$.

33) Dalton, A. J. : Micromorphology of murine tumor viruses and of affected cells. Federation Proc. $21: 936-941,1962$.

34) Dalton, A. J. : The Moloney agent. In : Tumors Iuduced by Viruses : ultrastructural studies. edited by A. J. Dalton and F. Haguenau, Acadcmic Press N. Y., pp 113-150, 1962.

35) Dalton, A. J. and Haguenau, F. : Tumors Iuduced by Viruses ; ultrastrural studics. Academic Press, N. Y., 1962.

36) Dalton. A, J., Haguenau, F. and Moloney, J. B. : Morphology of particles associated with murine leukemia as revealed by negative staining : preliminary report. J. Nat. Cancer Inst. $29: 1177-1179,1962$.

37) Dalton, A. J.. Hagnenau, F. and Moloney, J. B. : Further electron microscopic studics on the morphology of the Moloney agent. ibid. $33: 255-275,1964$.

38) Dalton, A. J., Law, L. W, Moloney, J. B. and Manaker, R.A.: An electron microscopic study of a series of murine lymphoid neoplasms. ibid. $27: 747-759,1961$.

39) Dalton, A. J., Potter, M. and Mervin, R. M. : Some ultrastructural characteriatics of a series of primary and transplanted plasma-cell tumors of the mouse. ibid. $26: 1221-1267$, 1961.

40) de Harven, E. : Ultrastructural studies on three different types of mouse leukemia : a review. In : Tumors Induced by Viruses : vltrastructural studies. Academic Press. N.Y. 1962.

41) de Harven, E. and Friend, C.: Electron microscupe study of a cell-free induced leukemia of the mouse : a preliminary report. J. Biophys. Biochem. Cytol. 4 : 151-156, 1948

42) de Harven, E. and Friend, C. : Electron microscopy of Swiss mouse leukemia virus. NCI monograph No 4, 291-311, 1960.

43) de Harven, E. and Friend, C. : Further electron nicroscope studies of a nouse leukemia induccd by cell free filtrates. J. Biophys. Biochem. Cytol. $7: 747-752,1960$.

44) de Harven, E. and Friend, C. : Structure of virus particles partially purified from the blood of leukemia mice. Virology $23: 119-$ 124, 1964.

45) Dourmashkin, R. R. : Electron microscopy of polyoma virus: a review. In: Tumors Induced by Viruses : ultrastructural studies, Academic Press, N. Y. pp. 151-182, 1962.

46) Dourmashkin, R. R. and Bernhard, W.: A study with the electron microsope study of the skin tumour of molluscum contagiosum. J. Ultrastructure Res. $3: 11-38,1959$.

47) Dourmashkin, R. R. and Negroni, C. ; Iden tification with the electron microscope of particles associated with polyoma virus in induced parotid gland tumours of $\mathrm{C}_{3} \mathrm{H}$ mice. Exp. Cell Res. $18: 573-576,1959$.

48) Dourmashkin, R. R. and Simons, P.J.: The 
ultrasructure of Rous sarcoma virus. J. ultrastructure Res. 5:505-522, 1961.

49) Drochowski, L. : Studies on human leukemia. Proc. Soc. Exp. Biol. Med. 101 : 686-690, 1959,

50) Dmochowski, L. : Virus and tumors. Science 133: 551-561, 1961.

51) Dmochowski, L. : The electron microscopic view of virus-host relationship in neoplasia. In : Progr. exp. Tumor Res. Vol. 3, Karger, Basel, N. Y. pp 35-147, 1963.

52) Dmochowski, L.: personal Communication.

53) Dmochowski, L. and Grey, C. E. : Subcellular structures of possible viral origin in some ma mmalian tumors. Ann. NY Acad. Sci. 68: $559-615,1957$.

54) Ducochowski, L. and Grey, C. E. : Electron microsi opy of tumors of knwon and suspected viral etiology. Texas Rcp, Biol. Mcd. 15 : 705-746, 1957.

55) Dmochowski, L., Grey, C, E., Berezky, E. and Blicharski, J. : Intracellular structures in tumors induced by polyoma virus. Nature $196: 610-612,1961$.

56) Dmochowski, L., Grey, C. E. and Burmester, B. R. : Studies on submicroscopic structure of chicken leukosis : lymphomatosis, erytroblastosis and granuloblastosis. Acta Internat. contra Cancrum $15: 780-790,1959$.

57) Dmochowski, L., Grey, C. E. and Gross, L. : The role of viruses in X-ray induced leukemia. In : Radiation Biology and Cancer. University of Texas Publications, pp. 382-399, 1958.

58) Dmochowski, L., Grey, C. E. and Magee L. A. : Studies on a virus ("polyoms") inducing multiple tumors in aminals. Proc. Soe. Exp. Bial. N. Y. $102: 174-179,1959$.

59) Dmochowski, L., Grey C. E., Padgett, F., and Sykes, J. A. : Studies on the structure of the mammary tumor-inducing virus (Bittner) and of leukemia virus (Gross). In : Viruses, $\mathrm{Nu}$ cleic Acid, and Cancer. The Williams and Wilkins Co., Baltimore, pp 85-121, 1463.

60) Dmochowaki, L., Grey, C. E., Pearson, L. O., Ward, D. N., Hurlbert, R. B., Griffin, A. C., and Bresson, A. L., : Studies on mammary tumorjnduclng virus in mice (Bittner). Proc. Soc, Exp. Biol., N. Y. 102: 174-179, 1959.

61) Dmochowski, L., Grey, C. E., Sykes, J. A., Dreyer, D. A., Langford, P., Jesse, R. H. Jr., MacComb, W. S. and Ballantyne, A. J. : A study of submicroscopic structure and of virus particles in cells of human laryngeal papillomas. Texas. Rep. Biol. Med. 22 : 454-491, 1964.

62) Eckert, E. A., Sharp, D. C., Beard, D., Green, I. and Beard, J, W. : Virus of avian erythromyeloblastic leukosis. IX. antigenic constitution and immunologic characterization. J. Nat. Cancer Inst. 16 : 593-643, 1955.

63) Eddy, B. E., Borman, G. S., Grubbs, G. E. and Young, R. D. : Identification of the oncogenic substance in rhesus monkey kidney ccll cultures as simian virus 40. Virology $17: 65-75,1962$.

64) Edwards, G. A., Buffett, R. F. and Furth, J. : The micromorphology of a salivary-gland tumor of a nouse infected with polyoma virus. J. Nat. Cancer Inst. $25: 25-51,1960$.

65) Erlandson, R. A. : A New Maraglass, D. E. R. (B) 732, embeddment for electron microscopy.

J. Cell Biol. 22 : 704-709, 1964.

66) Epstein, M. A. : Observation on the Rous virus; purification and identification of the perticles from solid tumours. Brit. J. Cancer $11: 268-273,1957$.

67) Epstein, M. A., Achong, B, G. and Barr, Y. M. : Virus particles in cultured lymphoblasts from Burkitt's lymphoma. Lancet $1: 702-703$, 1964.

68) Fawcett, D. W. : Electron microscopic observations on intracellular virus-like particles associated with the cells of the Lucke renal adevocarcinoma. J. Biophys. Biochem. Cytol. $2: 725-741,1956$.

69) Febvre, H. : The Sbope fibroma virus of rabbit. In : Tumors Induced by Viruses : ultrastructural studies. Academic Press, N. Y. pp. $79-111,1962$.

70) Feldman, D. G. : Origin and distribution of virus-like particles associated with mammary 
tumors in DBA strain mice. I. Virus-like particles in mammary gland tissue. J. Nat. Cancer Inst. $30: 477-501,1963$.

71) Feldman, D. G. : Origin and distribution of virus-like particles associated with mammary tumors in DBA strain mice. II. virus-like particles in the blood and organ. ibid. 30 : 503-515, 1963.

72) Feldman, D, G. : Origin and distribution of virus-like particles associted with mammary tumors in DBA strain mice. III. virus-like particles in transplanted tumors. ibid. $30: 517-531$, 1963.

73) Feldman, D, G., Gross, L. and Dreyfuss, Y. : Electron microscopic study of the passage A mouse leukemia virus in mammary gland of pregnant virus-injected, $\mathrm{C}_{3} \mathrm{H}$ (f) mice. Cancer Res. 23 : 1604-1607, 1963.

74) Fink, M. A. and Maln gren, R, A. : Fluorescent antibody studies of the virel antigen in a murine leukemia (Rauscher). J. Nat. Cancer Inst. 31 : 1111-1121, 1963.

75) Friedlaender, M. and Moore, D. H. : Occurrence of bodies within endoplasmic reticulum of Ebrlich ascites tumor cells. Proc. Soc. Exp. Biol. Med. 92 : 828-831, 1956.

76) Gaylord, W. H. and Hsiung, G. D. : the vacuolating virus of monkeys. II. virus morphology and intranuclear distribution with some histochemical observations. J. Exp. Med., $114: 987-996,1961$.

77) Goedfeder, A., Gelber, G. and Moore, D. H. : An electron microscope study of spontaneous mammary carcinomas in a subline of strain DBA mice. J. Nat. Cancer Inst. $25: 827-$ 845,1960 .

78) Graffi, A., Bierwolf, D., Baumbach, L., Blankenhagel, H., Widmaier, R. and Randt, A. : Viruspartikel in Zellen myeloischer Leukaemien des Menschen. Das deut. Gesundheitswesen. 1576-1580, Heft 35/1964.

78a) Graffi, A., Heine, U., Helmcke, J, G., Bierwalf, D. and Randt, A. Über den elektromikroskopischen Nachweiss von Viruspartikeln bei der myeloischen Leukämie der Maus nach
Injektion zellfreier Tumorfiltrate. Klin. Wochschr. 38, 254-262, 1960.

79) Girardi, A, J., Sweet, B. H., Slotnick, V. B. and Hilleman, M. R. : Development of tumors in hamsters inoculated in the neonatal period with vacuolating virus SV 40. Proc. Soc. Exp. Biol. Med. 109 : 649-660, 1962.

80) Granboulan, N., Riviere, M. R. and Bernhard, W.: Présence de particules dáspect viral dans un sarcome greffable de la souris provoqué par le méthylcholanthréne. Bull. Cancer. $7: 291$ $-307,1960$.

81) Gross, L. : Mouse leukemia : an egg-borne virus diseae (with a note on mouse salivary gland carcinoma). Acta Haematol. $15: 13-$ $29,1955$.

82) Gross, L. : Attempt to recover filtrable agent from X-ray-induced leukemia. ibid. $19: 353$ -361, 1958.

83) Gross, L. : Serial cell-free passage of a radiationactivated mouse leukemia agent. Proc. Soc. Exp. Biol. Med. $100: 102-105,1959$.

84) Gross, L. : Oncogenic Viruses. Pergamon Press, N. Y. 1961.

85) Gross, L. : Transmission of mouse leukemia virus through milk of virus injected $\mathrm{C}_{3} \mathrm{H}$ female mice. Proc. Soc. Exp. Biol. Med. 108 : 715-723, 1961.

86) Guy de Thé, Heine, H., Sommer, J. R. , Arvy, L., Beard, D. and Beard, J. W.: Multiplicity of cell response to the BAI strain A (mjeloblastosis) avian tumor virus. IV. ultrastructural characters of the thymus in myeloblastosis and of the adenosintriphosphatase activity of thymic cells and associated virus. J. Nat Cancer Inst. $30: 415-455,1963$.

87) Guy de Thé, Ishiguro, H., Beard, D. and Beard. J. W. : Multiplicity of cell response to the BAI strain A (myeloblastosis) avian tumor virus. VII. elaboration of virus by nonneoplastic hepatic cells. ibid. $31: 717-729$, 1963.

88) Guy de Thé, Ishiguro, H., Heine, U., Beard, D. and Beard, J. W. : Multiplicity of cell response to the BAI strain A (mjeloblastosis) 
avian tumor virus. V. ultrastructural aspects of adenosintriphosphatase activity of nephroblastoma cells and virus. ibid. $30: 1267-1301$, 1963.

89) Haguenau, F. : Le cancer du sein chez la femme. étude comparative au microscope électronique et au microscope optique. Bull.

Assoc. franc. étude cancer $46: 172-211,1959$.

90) Haguenau, F. : Significance of ultrastructure in virus-induced tumors. NCI monograph No4, 1960.

91) Haguenau, F. and Beard, J. W. : The avian sarcoma-leukosis complex; its biology and ultrastructure. In : Tumors Induced by Viruses : ultrastructural studies. Academic Press, N. Y. pp. $1-59,1962$,

92) Haguenau, F., Dalton, A. J. and Moloney, J.B. : A preliminary report of electron microscopic and bioassay studies on Rous sarcoma I virus. J. Nat. Cancer Inst. $20: 633-650$, 1958.

93) Haguenau, F., Febrre, H. L. and Arnoult, J. : Ultrastructure de virus du sarcome de Rous cultivé in vitro. Compt. rend. acad. sci. $250: 1477-1479,1960$.

94) Hanafusa, H., Hanafusa, T. and Rubin, H: The defectiveness of Rous sarcoma virus. Proc. Nat. Acad. Sci. $49: 572-580,1963$.

95) Heine, U., Beaudreau, G.S., Becker, C., Beard, D. and Beard, J.W. : Virus of avian erythroblastosis. VII. Ultrastructure of erythroblasts from the chicken and from tissue culture. J. Nat. Cancer Inst. $26: 359-388,1961$.

96) Heine, U., Becker, C., Bonar, R. A. and Beard, J. W.: Segregation of gold particles in gray bodies of myeloblasts infected with BAI strain A avian tumor virus : preliminary report. ibid, $31: 731-739,1963$.

97) Heine, U., Guy de Thé, Beard, D. and Beard, J. W. : Multiplicity of cell response to the BAI strain A (myeloblastosis) avian tumor virus. V. elaboration of virus by pancreas of chicsens inoculated with the agent. ibid. $30: 817$ $-835,1963$.

98) Heine, U., Guy de Thé, Ishiguro, H. and
Beard, J. W. : Morphologic aspects of Rous sarcoma virus elaboration. ibid. $29: 211-223$, 1962.

99) Heine, U., Guy de Thé, Ishiguro, H., Sommer, J. R., Beard, D. and Beard. J. W. : Multiplicity of cell response to the BAI strain A (myeloblastosis) avian tumor virus II. nephroblastoma (Wilm's tumor) : ultrastructure. ibid. $29:$ 41-105, 1962.

100) Henle, G., Deinhardt, F. and Rodriguez, J. : The development of polyoma virus in mouse embryo cells as revealed by fluorescent antibody staining. Virology $8: 388-391$, 1959.

101) Higashi, N., Ozaki, Y. and Ichimiya, M. : Electron microscopy of pox virus-to-cell adsorption and the ultrastructure of developmental forms of pox virus. J. Ultrastructure Res. $3: 270-281,1960$.

102) Hiraki, K., Ota, Z., Suzuki, S. and Muguruma, M. : Electron microscopic study of mammary cancer developed in a ligh leukemic strain $\mathrm{C}_{58}$ mice. Gann $56: 81-81,1965$.

103) Hiraki., K., Irino, S., Ota, Z., Miyoshi, I., Harada, H., Suzuki, S. and Sato, M. : Prodducfin of $C$ particles by culture of AKR mammary carcinoma cells. ibid. $55: 443-445$. 1964.

103a) Hiraki, K., Irino, S., Ota, Z., Miyoshi, I., Suzuki, S. and Sato, M. : An electron microscopic Study of spontaneous mammary carciroma in AKR mice. ibid. $55: 245-249,1964$.

1.04) Hollmann, K. : Infectious papillomatosis of rabbits (Shop.e) : biology and ultrastructure. In : Tumors Indnced by Viruses : ultratructural studies. Academic Press, N. Y. pp. 61 $-78,1962$.

105) Horne, W. E., Waterson, A. P., Wildy, P. and Farnham, A. W. : The structure and composifion of the Myxoviruses. I. electron microscope studies of the structure of Myxovirus particles by negative stainig techniques. Virology $11: 79-98,1.960$.

106) Howatson, A. F. : the structure of tumor viruses and its bearing on their relation to 
viruses in general. In : Advances in Cancer Research. edited by A. Haddow and S. Weinhouse. Academic Press, N. Y. pp 1-40, 1964.

107) Howatson, A. F. aud Almeida, J. D. : An electron microscope study of polyoma virus in hamster kidney. J. Biophys. Biochem. Cytol. $7: 753-760,1960$.

108) Howatson, A. H. and Crawford, L. V. : Direct counting of the capsomeres in polyoma and papillona viruses. Virology $21: 1-6$, 1963.

109) Howatson, A. F. and McCulloch, E. A. : Virus-like bodies in a transplantable mouse plasma cell tumor. Nature $181: 1213-1214$, 1958.

110) Howatson, A. F., Mc Culloch, E. A., Almeida, J. D., Siminovitch, L., Axelred, A. A. and Ham, A. W. : Studies in vitro, in vivo, and by electron microscope of a virus recovered from a $\mathrm{C}_{3} \mathrm{H}$ mouse mammary tumor. relationship to polyoma virus. J. Nat. Cancer Inst. 24 : 1131-1151, 1960.

111) Huebner, R. J., Rowe, W. P. and Lane, W. $T$. : Oncogenic effects in hamsters of human adenovirus type 12 and 18. Proc. Nat. Acad. Sci. $48: 2051-2058,1962$.

112) Hummel, K. P. and Little, C. C. : Studies on the mouse mammary tumor agent. III. survival and propagation of the agent in transplanted tumors and in hosts that grew these tumors in their tissues. Cancer Res. 9:137 $-138,1949$.

113）北房秀三郎：RNAウイルスによる発カン. 蛋 白質核酸酵素 $9: 1094-1099 ， 1964$.

114）畑中正一：カンウイルス— 今までの成果と これからの問題 问誌 $9: 167-175,1964$.

115）平木絜：ウイルス性腫境の免疫学的研究，癌 の臨床 $8: 663-620,1962$.

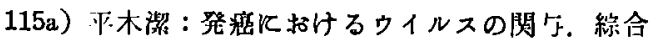
躒床 $13: 885-895,1964$.

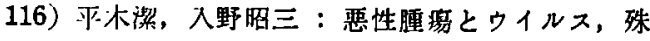
に放射線喘とウイルスについて，同誌 14:10 $-25,1965$

117）平木橴，入野招三，太时盖们，瀨崎達雄：20一 wcthylcholanthrene 誘発 RF系ハツカネズ白
监病におけるゥイルスの電子顕微鏡による証明

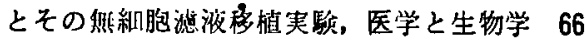
: 191-1.98, 1963.

118）雨木滋，入野沼三，太田善介，濑崎達雄，須 崎正則，永森俤一郎，鈴木信也，大里尚司：白

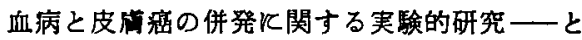
く飞皮瘦におけるウイルス粒子の電顕的証明. 医学のあゆみ $49: 701-707,1964$.

119）承木潔，人野炤三，濑崎達雄，須崎正則：20methylcholanthrene Kより惹起せしめた RF 系 マウス白血病の無細胞滤液移植に関する研究.

日血会誌 $25: 822-830 ， 1962$.

120）巫木潔，入野昭三，宗田䇛，池尻考治：X 線 照射により若起せしめた RF 系マウス白血病の 無細胞渍液移植に関する研究，同誌 $25: 816$ $-821,1962$.

121）東昇，石田名香雄編集：ウイルス学 朝倉書店 東京 1964.

122) Ida, N., Moloney, J. B. and Taylor, H. G.: Placental transmission of sarcoma-37 leukemia virus. Res. Report, University Texas, M. D. Anderson Hospital and Tumor Inst. 198199. 1960 .

123) Inman, D. R., Woods, D. A. and Negroni, G. : Electron microscopy of virus particles in cell cultures inoculated with passage fluid from human leukaemic bone-marrow. Brit. med. J. $1: 929-931,1964$.

124) Irino, S., Ota, Z., Sezaki, T., Suzaki, M. and Hiraki, K. : Cell-free transmission of 20methylcholanthrene-indnced RF mouse leukemia and electron microscopic demonstration of virus particles in its leukemic tissue. Gann. $54: 225$ -237, 1963.

125) Ito, Y.: Relationship of components of papilloma virus to papilloma and carcinoma cells. Cold Spring Harbor Symp. Ouant. Biol. 27 : 387-394. 1962.

126) Iwakata, S. and Grace, J. T. : Cultivation in vitro of myeloblasts from human leukemia. N. Y. State J. Med. Sept. $15: 2279-2283$, 1964.

127) Iwakata, S. and Ichikawa, Y. : An electron microscopic Study on the virus liberation of erythroblastosis cells in mitosis. Acta Haematol. 
Jap. $23: 767-775,1960$.

128）市川康夫：ウイルス性白侐病及び癌における ウイルス粒子と“偽ウィルス柆子”の生成形態 そついて，日血会誌 $22: 539-552 ， 1959$.

129）市川康夫, 野竹那弘：螢光抗体法火よるマウ ス白血病ウイルスの研究. 䖈の臨林 8:655一 $663,1962$.

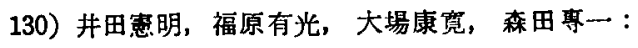
白血病ウ1ルスの自然垂直感杂に就て，綜合臨 床 $13: 1898-1902,1964$ 。

131）今井渨：ウイルス腫湐の宿主ウイルス関係。 癌の臨床 $8: 231$-237, 1962.

132）今井環, 岡野博光：超溥連続切片によるマウ 又乳癌絊胞の観察、第23回日本癌学会総会抄録 集 1964 .

133）入野昭三，太田善介，宗田範：X線誘発 RF 系 ハッカネスミ白血病におけるウイルスの電子顕

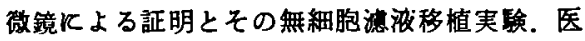
学と生物学 $67: 162-168,1963$.

134）伊藤洋平：PAPOVA ウイルス群，ウイルス学 東昇，石田名香雄糄集 朝倉書店 東京 293301, 1964.

135）岩片捨登志：家舀赤芽球症ウイルス抗原の細 盷内分布。日血会誌 $24: 584-590,1961$.

136) Kato, S., Takahashi, M., Miyamoto, H. and Kamahora, J. : Shope fibroma and rabbit myxoma virus. I. autoradiographic and cytoimmunological studies on " $B$ " type inclusions.

Biken J. 6 : 127-134, 1963.

137) Kinoshita, R. and Takefuda, T. : Virus particles of mouse lymphomas and mammany carcinoma. In : Viruses, Nucleic Acids and Cancer. The Williaws and Wilkins Co., Baltimore, pp. 141-147, 1963.

138) Knight, C. A. : Precipitin reactions of highly purified influeuza viruses and related materials.

J. Exp. Med. 85 : 99-116, 1947.

139）春日孟, 太田那夫：Friend 病の病理学的性格。 澏の臨床 8:251-256, 1962.

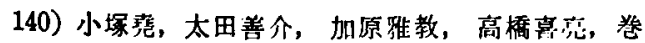
幡徹：螢光抗体法飞よる董場の免拨学的研究.

第 1 報 C59 マゥス白血病におけるゥイルス抗原 の分布について，癌の臨床 $9: 302-307$. 1963.

141) Lasfargues, E. Y., Moore, D. H., Murray,
M. R., Haagensen, C. D. and Pollard, E. C. : Production of milk agent in cultures of mouse mammary carcinoma. J. Biophys. Biochem. Cytol. 5 : 93-96, 1959.

142) Lasfargues, E. Y., Murray, M. R. and Moore, D. H. : Cultivation of the mouse mammary carcinoma virus. NCI monograph No. $4: 151$ 166, 1960.

143) Law, L. W. and Moloney, J. B. : Studies of congenital transmission of a leukemia virus in mice. Proc. Soc. Exp. Biol, Med. 108 : 715723, 1961.

144) Liebelt, R. : In: Viruses, Nucleic Acids and Cancer. The Williams and Wilkins Co. Baltimore. pp. $566-570,1063$.

145) Lieberman, M. and Kaplan, H. S. : Leukenogenic activity of filtrates from radiationinduced lymphoid tumors of mice. Science 130 : 387-388, 1959.

146) Lloyd, B. J. Jr. and Kahler, H. : Electron microscopy of the virus of rabbit fibroma. J. Nat. Cancer Inst. $15: 991-994,1955$,

147) Lunger, P. D. : Thin-section electron microscopy of the mature Lucké frog kidney tumor virus. Virology $22: 285-286,1.964$,

148) Lunger, P. D.: The isolation and morphology of the Lucké frog kidney turor virus. ibid. $24: 138-145,1964$.

149) Lyons, M. J. and Moore, D. H.: purification of the rouse mammary tumor virus. Nature 194 : 1141.-1142, 1962.

150) Malmgren, R. A., Rabotti, G. and Robson, A. S. : Intracellular localization of polyoma virus antigen demonstrated with fluoresceinlabeled antiserum. J. Nat. Cancer Inst. 24. $581-587,1.960$.

151) Manaker, R. A., Strother, P. C., Miller, A. A. and Piczak, C. V.: Behavior in vitro of a rouse lymphoid-leukemia. virus. ibid. 25 : 1411-1.41.9, 1960.

152) Manaker, R. A., Jensen, E. M. and Koral, W. : Long-term propagation of a murine leukemia virus in an established cell line. ibid. 33 : 363-371, 1964.

153) Mannweiler, K. and Bernhard, W. : L'ultra- 
structure du myxosarcome de Fujinami. Bull Cancer $45: 223-236,1958$.

154) Mattern, C. F. T. : Polyoma and papilloma viruses : do they have 42 or 92 subunits? Science $137: 613-615,1962$.

155) Mellors, R. C. : Tumor cell localization of the antigens of the Shope papilloma virus and the Rous sarcoma virus. Symposium Cancer Res. $20: 744-746,1960$.

156) Melnick, J. L. : Papove virus group. Science $135: 1128-1130,1962$.

157) Moloney, J. B.: The murine leukemias. Fede ration Proc. 21 : 19-31, 1962.

158) Morgan, C., Howe, C. and Rose, H. M. : Structure and development of viruses as observed in the electron microscope. V. Western equine encephalomyclitis virus. J. Exp. Med. $113: 219-234,1961$.

159) Morgan, C.. Howe, C., Rose, H. M. and Moorc, D. H. : Structure and development of viruses observed in the electron microscope. IV. viruses of the RI-APC group. J. Biophys. Biochem Cytol. 2 : 351-360, 1956.

159a.) Morgan, C., Rifkind, R. A. and Rose, H. M.: The use of ferritin-conjugated antibodies in electron microscopic studies of influeuza and vaccinia viruses. Cold Spring Harbor Symp. Quant. Biol. 27 : 57-65, 1962.

160) Morgan, C., Rose, H. M. and Moore, D. H. : Struçture and development of viruses observed in the electron microscope. III. Influenza virus. J. Exp. Med. 104 : 171-182, 1956.

161) Morgan, C., Rose, H. M., Holden, M. and Jones, E. P.: Electron rricroscopic observations on the development of herpes simplex virus. ibid. $110: 643-656,1959$.

162) Moore, D. H. : The milk agent. In : Tumors Indnced by Viruses : ultrastructural studies. Academie Press, N. Y. pp. 113-150, 1962.

163) Moore, D. H. : On the identification and characterization of the milk agent. In : Ciba Foundation Symposium on turror viruses of murine origin. Little, Brown and Co. Boston, pp. 107-137, 1962 .

161) Moore, D. H., Lasfargues, E. Y., Murray,
M. R., Haagensen, C. D. and Pollard, E. C. : Correlation of physical and biological properties of mouse mammary tumor agent. J. Biophys. Biochem. Cytol. 5 : 85-92, 1959.

165) Moore, D. H. and Lyons, M, L. : Eleotrophoretic separation of the mouse mammary tumor virus. J. Nat. Cancer Inst. $31: 1255-1273$, 1963.

166) Moore, D. H., Stone, R. S., Shope, R. E. and Gelber, P. : Ultrastructure and site of formation of rabbit papillora virus. Proc. Soc. Exp. Biol. Mcd. 101 : 575-578, 1959.

167) Murphy, W.H.: Possible association between leukemia in children and virus-like agents. J. A. M. A. $191: 110-115,1965$.

168）松井敬介：日本跕床 $21: 1248 ， 1963$.

169）松井敬介，森脇明介： マウス乳癌ウイルスの 電子顕微鏡的研究——特にゥイルスの形態， 発生，增殖及び成熟について. 米子医学雑誌 $13: 25-51,1962$.

170）宮脇英夫：Hormone-dependent tumor とウイ ルス—乳腺 hyperplastic nodule $の$ 電子顕微 鏡的観察. 癌の臨床 8:265一272. 1962.

171) Negroni, G. : Isolation of viruses from leukemic patient. Brit. med. J. 1 : 927-929, 1964.

172) Negroni, G., Dourmashkin, R. R. and Chesterman, F.C. A "polyoma" virus derived from a mouse leukemia. Brit. med. J. 2 : 1329-1360, 1959 .

173) Nishiumi, Y., Okano, H. and Imai, I.: Inoculation of chicken sarcoma virus into chicken thymus. an elcetron microscopy (26544). Proc. Soc. Exp. Biol. N. Y. $107: 88-90,1961$.

174) Noyes, W. F. : Studies on the Shope rabbit papilloxa virus. II. The location of infective virus in papillomas of the cottontail rabbit.

J. Exp. Med. $109: 423-438,1959$.

175）野竹扼弘, 市川康夫, 花岡正男, 天野重安： マウス正常招よび白血病性淋巴球の長期体外培 婊と白血病ウイルス—細胞の同時培盖につい て. 日血会誌 $24: 591-609 ， 1961$.

176) Oberling, C., Bernhard, W. and Viger, P.: The internal structure of the virus-like particles associated with Rous sarcome and presence in other neoplastic and normal chicken tissues. 
Nature $180: 386-387,1957$.

177) O'coner, G. T., Rabson, A. S., Berenzesky,

I. K. and Paul, F, J. : Mixed infection with simian virus 40 and adenovirus 12 . J. Nat. Cancer Inst. 31 : 903-917, 1963.

178) Okano, H., Kunii, A. and Furth, J. : An electron microscopic study of leukemia induced in rats with Gross virus. Cancer Res. : 23 : $1169-1175,1963$.

179) Ota, Z. : Electron microscope study of the development of Japanese $B$ encephalitis virus in porcine kidney stable (PS) cells. Virology 25 : 372-378, 1965.

180) Ota, Z., Suzuki, S. and Higashi S. : Viruslike particles in human chloroleukemia cells. Gann 54 : 481-486, 1963.

181）太田善介：腫場性ウイルス粒子の電顕的研究. 綜合臨床 $13: 1902-1905,1964$.

182) 太田善介, 鈴木信也, 東悟：ヒト緑色白血病 細胞間に認められたウイルス様粒子の電顕像. 医学と生物学 $67: 197-200,1963$.

183）太田善介，高橋建次，鈴木信也，六車昌士 : 日本脳炎ゥ1ルスの PS 細胞内増殖飞関する電 子影微鏡的研究. 日本伝染病学会誌 $38: 66-$ $79,1964$.

184) Parsons, D. F. : Negative staining of thinly spread cells and associated virus. J. Biophys. Biochem. Cytol. $16: 620-626,1963$.

185) Parsons, D, F. : Structure of the Gross leukemia virus. J. Nat. Cancer Inst. $30: 569-$ 583, 1963.

186) Parsons, D, F., Upton, A. C., Bender, E. S. and Johnson, R. R. : Electron microscopic observations on primary and serially passaged radiation-induced myeloid leukemias of the RF mouse. Cancer Res. 22 : 728-736, 1962.

187) Pearson, H. E. and Baker, R. F. : Some electron-dense particles associated with certain murine tumors. J. Nat. Cancer Inst. $29: 491$ $-513,1962$.

188) Peries, J., Levy, J. P., Boiron, M. and Bernhard, J.: Multiplication of Rauscher virus in cultures of mouse kidney cells. Nature 203 : 672-673, 1964.

189) Pitelka, D, R., De O.ne, K, B. and Bern,
H. A. : Virus-like particles in precancerous hyperplastic mammary tisses of $\mathrm{C}_{3} \mathrm{H}$ and $\mathrm{C}_{3} \mathrm{Hf}$ mice. J. Nat Cancer Inst. $25: 753-778$, 1960.

190) Porter, III, F. H., Dalton A. J., and Moloney, J. B, : Association of electron-dense particles with human acute leukemia. ibid. $33: 547$ 556, 1964.

191) Rafferty, K. A. Jr. : Kidney tumors of the leopard frog. a review. Cancer Res. $24: 169$ -185, 1964.

191a) Rauscher, F. J. : A virus-induced disease of mice characterized by erythrocytopoiesis and lymphoid leukemia. J. Nat Cancer Inst. 29 : 515-543 .1962.

192) Richter, H.: Elektronenmikroskopischer Bcitrag zur Ätiologie der Lymplogranulonatose. Münch. med. Wchnschr. $20: 889-890,1959$.

193) Rubin, H. and Vogt, P.: An avian leukosis virus associated with stock of Rous sarcona virus. Virology $17: 184-194,1962$.

194) Sanford, K. H., Andervont, H. B., Hobbs, G. L. and Earle, W. R. : Maintenance of the mammary-tumor agent in long term cultures of mouse mammary carcinoma. J. Nat. Caacer Inst. $26: 1185-1191$, , 1961.

195) Selickson, A.S. and Lynch, F. W.: Electron microscopy of virus-like particles in a keratoacanthoma. J. Invest. Dermat. $37: 79-81$, 1961.

196) Shimizu, T. and Rubin, H.: The dual origin of noninfective Rons sarconas. J. Nat Cancer Inst. $33: 79-91,1964$.

197) Smith, K. O., Benyesh-Melnick, M. and Fernback, D. J. : Studies on human leuke nia. II. Structure and quantitation of myxoviruslike particles associated with human leukenia. ibid. 33: 557-570, 1964.

198) Sobin, L. H. : Virus-like particles in the cells of lymphoma 6C 3 HED. Cancer Res. $24: 64-$ $69,1964$.

199) Sorenson, G, D. : Electron microscopic observations of viral particles within myelona cells of man. Exp. Cell Res. $25: 219-221,1961$.

200) Stone, R, S. and Moore, D. H. : Purification 
of mouse mammary agent by means of a fluorocarbon. Nature $183: 1275-1276,1959$.

201) Stone, R. S., Shope, R. E. and Moore, D. H. : Electron microscope study of development of the papilloma virus in the skin of the rabbit.

J. Exp. Med. $110: 543-546,1959$.

202) Suzuki, T.: Electron microscopic cytohistopathology. (III). electron microscopic studies on spontaneous mammary carcinoma of mice. Gann $48: 39-56,1957$.

203) Sykes, J, A., Angerman, J. and D.nochowski, L. : Tissue culture studies of mouse mammary tumors. Proc. Am. Assoc. Cancer Res. 3 : $154,1960$.

204) Sykes, J. A., Grey, C. E., Scanlon, M., Young, L., Dnochowski, L.: Density gradicnt centrifugation studies of the Bittner virus. Texas R: p. Biol. Mcd. 22 : 609-627, 1961.

205) Symposia Tunor Viruses. National Cancer Institute Monograph No. 4. 1960.

206）新保幸太郎：ウイルス性腫場の本態的研究. 日新医学 $49: 8-18,1962$.

207) Takaki, F., Suzuki, T. and Yasuka, H. : Electron microscopic studies on malignant tumor cells. Electron microscopy. Proc. lst Regional Conf. Asia \& Oceania 206-213, 1956.

208) Takaki, F., Suzuki, T., Yasuda, H. Taguchi, S., Dohi, J. and Sasao, M. An electron microscopic study on molluscuin contagiosum. J. Tokyo Tikeikai School Mcd. 4 : 60--69, 1957.

209) Tanaka, T., Takefuda, T. and Kinoshita, R. : Experimental carcinogenesis by 4-Nitroquinoline-N-oxide (4NQO) . Proc. Am. Assoc. Cancer Res. $4: 67,1963$.

210) Thiery, M., de Groodt, M., de Rome, F., Sebruyns, M. and Lagasse, A. : Virus-like particles in chemically induced carcinoma of the uterine cervix. Nature $183: 649-695$, 1959.

211) Toth, B. : Development of malignant lymphomas by ccll-free filtrates prepared from a chemically induced mouse lymophoma. Proc. Soc. Exp. Biol. Med. 11? : 873-875, 1963.

212) Trentin, J. J., Yabe. Y. and Taylor, G. : The quest for human cancer viruses. Science
$137: 835-841,1962$.

213）高木文一：澏とウイルスに関する䉓子顕微鏡

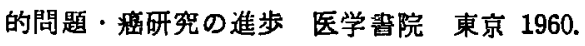

214) Van Iterson, W. and Ruys, A. C.: The fine structure of the Mycoplasmataceae (Microorganis.ns of the Pleuropneumonia group $=$ PPLO). 1. Mycoplasma hominis, M. fermentans and $M$. salivarium. J. Ultrastructare Res. 3:282$301,1960$.

215) Wildy, P., Russell, W. C. and Horne, R. W. : The morphology of herpes. Virology 12 : 204-222, 1060.

216) Wildy, P., Stoker, M. G. P., Macpherson, I. A. and Horne, R. W. : The fine structure of polyoina virus. Virology $11: 444-457,1960$.

217) Wiliams, M. G., Howatson, A, F, and Almeida, J. D. : Morphological characterization of the human common wartiverruca vulgaris). Nature 189 : 895-897, 1961.

218) Willians, R. C., Kass, S. J. and Knight, C. A. : Structure of Shope papillona virus particles. Virology $12: 48-58,1960$.

219) Woolley, G. H., Law, L. W. and Little, C. C. : The occurrence in whole blood of material influencing their incidence of mammary carcinona in mice. Cancer Res. I : 955-956, 1941.

220) Yasuzuni, G: A comparative electron microscopic study on Ehrlich ascites tumor cells, Yoshida sarcoma cells, and human cancerous peritonitis ascites cells. ibid. $18: 1167-1170$, 1958.

221) Zeigel, R.F.: Morphological evidence for the association of virus particles with the pancreatic acinar cells of the chick. J. Nat. Cancer Inst. 26 : 1011--1039, 1961.

222) Zeigel, R. F. and Rauscher, F. J. : Electron microscopic and bioassay studies on a murine leuke nia virus (Rauscher): preli ninary report. ibid. 30 : 207-219, 1963.

223) Zeigel, R, F. and Rauscher, F.R. : Electron microscopic and bioassay studies on a nurine leuke nia virus (Rauscher). I. effects of physiochemical treatnents on the morphology and biological activity of the virus. ibid. $32: 1277$ $-1307,1964$. 
224) Zucker-Franklin, D. : Virus like particles in the lymphocytes of a patient with chronic lymphocytic leukemia. Blood $21: 509-213$, 1963.

\section{写真 説 明}

写真 1. $\mathrm{C}_{3} \mathrm{H}$ 自然発生乳癌の $\mathrm{B}$ 型ウイルス柆子. 細胞膜上 3 ケ所よりゥイルス粒子の budding 像が見られ， 内部炡 A 型粒子を認める。倍事 $\times 200,000$

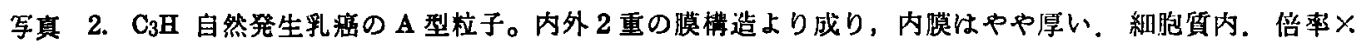
200,000

写真 3. $\mathrm{C}_{3} \mathrm{H}$ 自然発生乳癌の B 型ウイルス粒子．ウイルス粒子の表面に規則正しく配列した梀状突起をみ， 㤥様体に一致する構造に PTA の传人を認める。倍率 $\times 400,000$

写真 4. AKR 自然発生乳癌のB型ウイルス粒子. 矢印の部に梀状突剋が認められる。右下Kは budding 中 と思かれる 4 層の膜粠造より成る，核様体を欠くウイルス柆子がられる。倍率 $\times 400,000$

写真 5. AKR 自然発生乳㴽のB 型ウイルス柆子。中心部に核様体を欠ぐウイルス粒子 (budding 中の B 型 ウイルス粒子）が数ケ見られ，又核様体を2 有する柆子むみられる。倍率 $\times 200,000$

写真 6. AKR 自然発生乳痘の A 型粒子. コルシ野附近の封入体。倍率 $\times 53,000$

写真 7. AKR 自然発生乳满を in viroで 25 代継代した腫場組織内にみられたトーナッ型のウイルス粒子。 倍率 $\times 105,000$ 插入した写真は in vitroで21代継代した培細胞飞みられた $\mathrm{C}$ 型ウイルス粒子。

写真 8. $\mathrm{C}_{58}$ 自然発生白血病。リンパ腺内の C 型ウイルス柆子。細胞外. 倍率 $\times 200,000$

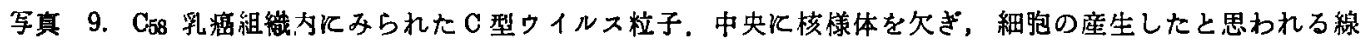
維粠造を内部有する異型ウイルス粒子がみられ，又核様体を欠文， 2 重模構造のみから成ると思 われるウイルス柆子る2，3 認められる。倍率 $\times 105,000$

写真 10. $\mathrm{C}_{58}$ 乳滛細胞を in vivo で 3 代継代した組織内の $\mathrm{C}$ 型ウイルス粒子。budding 像もみられる。倍率 $\times 120,000$

写真 11. $\mathrm{C}_{58}$ 乳赦細胞を in vivo で 3 代継代した組織内とみられた cylindrical form のウイルス粒子. 倍率 $\times 60,000$

写真 12. $\mathrm{C}_{38}$ 乳癌細泡を in vitro で艇代した第 3 代目の細狍。細跑間潭に多数の $\mathrm{C}$ 型粒子を認める。倍率 $\times 80,000$

写真 13. $C_{58}$ 乳癌ウイルス粒子の negative staining 像。中心部の㤥様体に一致する構造に PTA の曼入を認 める。倍率 $\times 140,000$

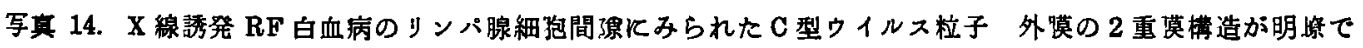
ある。倍率 $\times 220,000$

写真 15. 20-methylcholanthrene 誘発 RF 白血病のリンバ腺内白血病細泡より budding 中のウイルス粒子. ウイルス柆子は未だ細管構造（pedicel）飞よって細招と連って怙り，又核様体む形成されていない， 倍率 $\times 200,000$

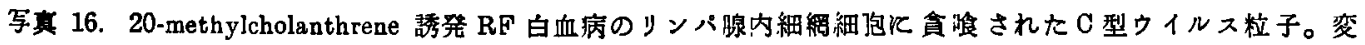
性しているゥイルス柆子も右上て数ヶみられる。倍率 $\times 160,000$

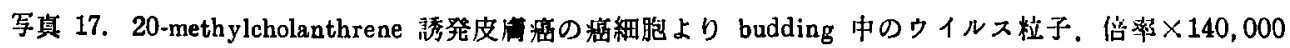

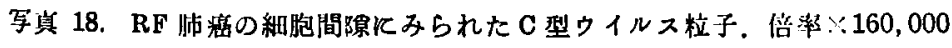

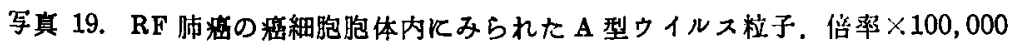

写真 20. 家赤芽球店ウイルス拉子 (W. Bernhard13) Kよる)

军真 21. 家袍赤芽球症ウイルス粒子の budding 像 (F. Haguenau, J.W. Beard91) Kよる)

写真 22. 培羡細胞核内飞增殖したポリオーマウイルス柆子（R.R. Dourmashkin45）飞よる）

写真 23. 七ト緑色白血病骨随内の白牦病細胞核内にみられた A 型封入体。倍率 $\times 60,000$

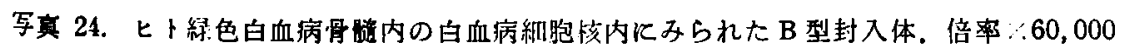

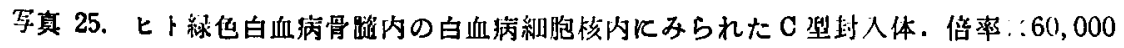

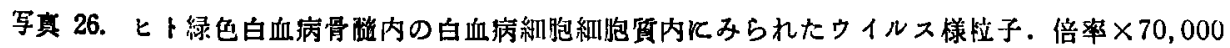




\title{
Morphology and Classification of Oncogenic Viruses
}

\author{
Kiyoshi Hiraki \\ Zensuke Ota \\ Shozo Irino \\ Isao Miyoshi \\ Tatsuo Sezaki \\ Hideo Harada \\ Shinya Suzuki \\ Yoshimori Ohsato \\ Teiichiro Nagamori \\ Junichiro Moriya \\ Masahito Muguruma \\ Kiyoshi Takasugi \\ Hiroshi Dabasaki \\ and \\ Kazuhiko Ikeda
}

Department of Internal Medicine (Director: Prof. K. Hiraki),

$$
\text { Okayama University Medical School, Okayama }
$$

Morphologic characteristics of most of known oncogenic viruses, some of which were investigated by us, were describəd in relation to their oncogenicity and their localizations in tumor tissues.

Oncogenic viruses were classified into six groups : type A, B, C, D, E and F. Viruses pertaining to type A were presumably not mature virus particles. Some of them could, however, be immature form or incomplete form of oncogenic virus particles. Viruses belonging to type B, C, D, E, and F were represented by mammary tumor virus of mice, leukemia viruses of mice and chickens, polyoma virus, Shope fibroma virus and Lucké renal adenocarcinoma virus, respectively. They were different in size and shape, and in the mode of development.

It was presumed that type $B$ and $C$ viruses were members of the Myxovisus group and type $\mathrm{D}$ viruses belonged to Adenovirus and the Papova virus group. It was also believed that type $\mathbf{E}$ and $\mathrm{F}$ viruses had in general the feature of the Pox virus group and Herpes virus group, respectively. 
平木外 13 名論文附図
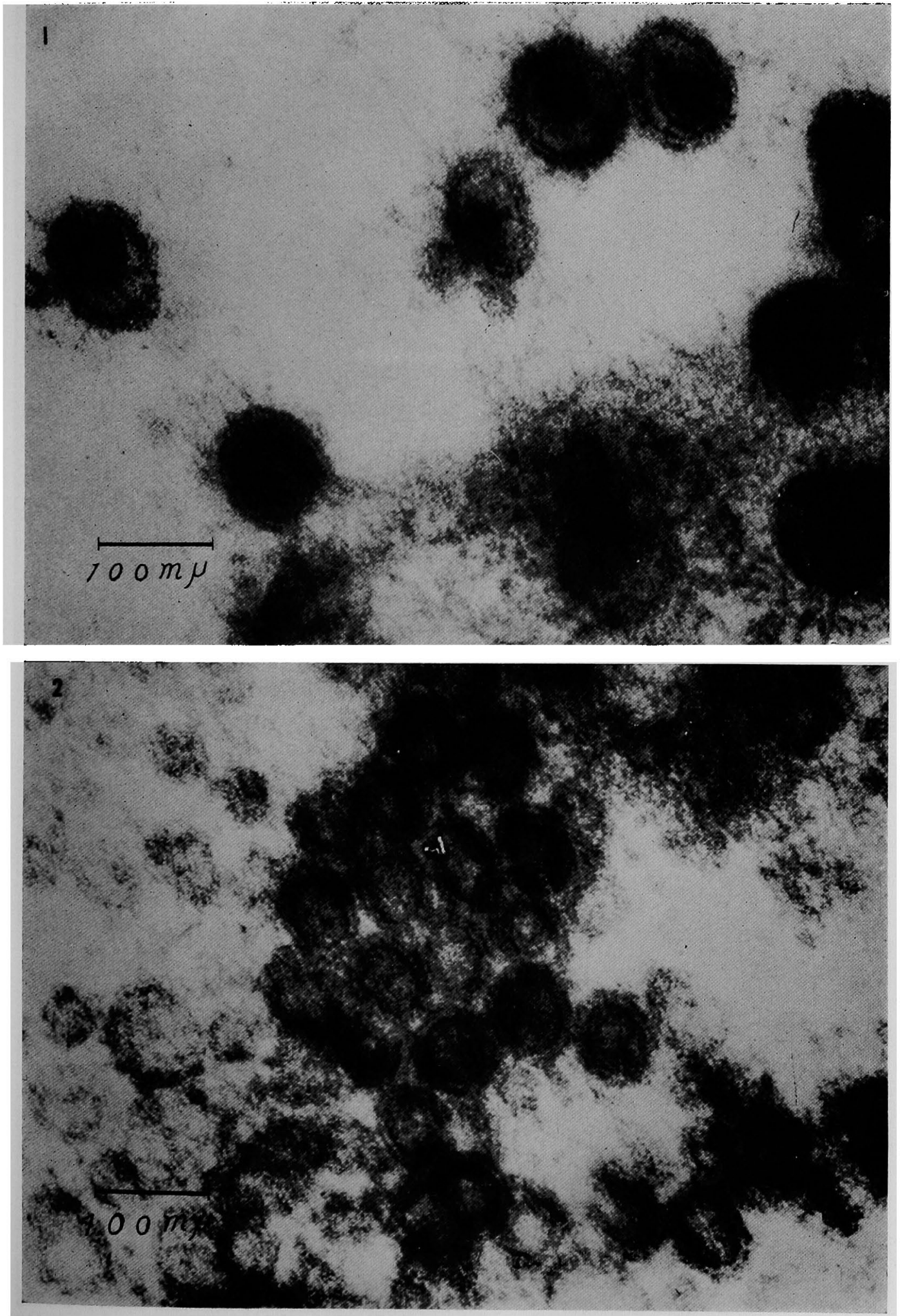
平木外 13 名論文附図
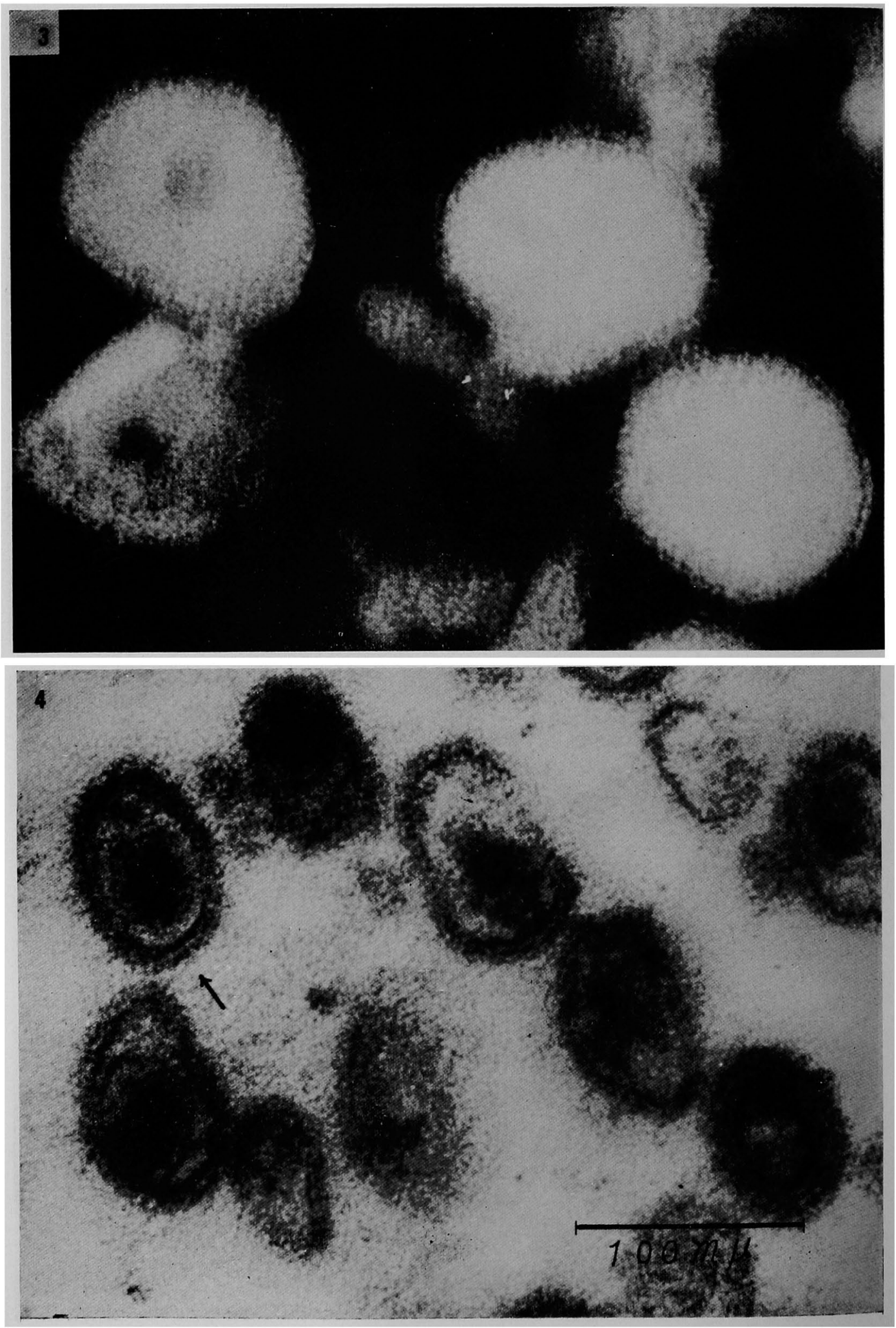
平木外 13 名論文附図

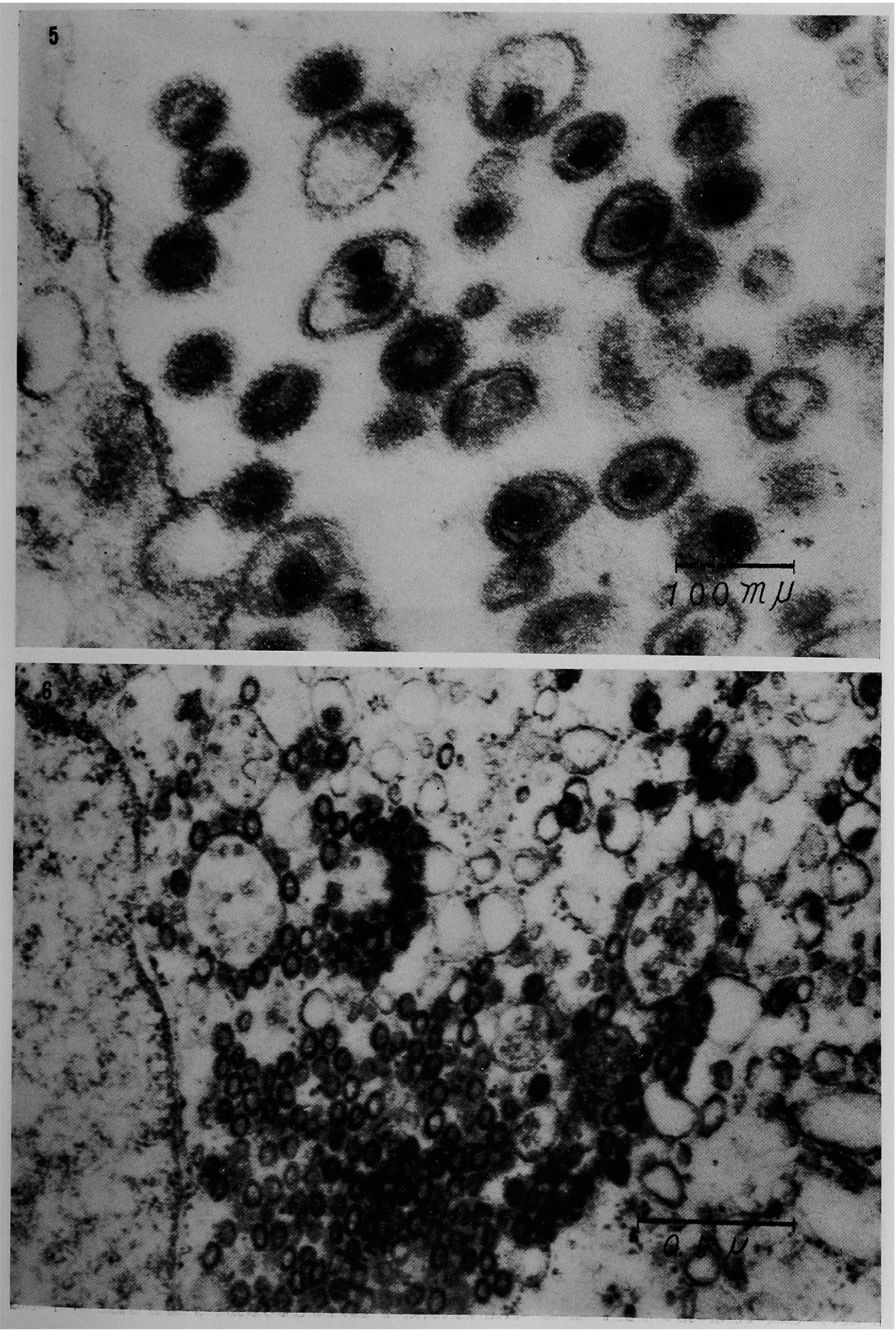


平木外 13 名論文附図
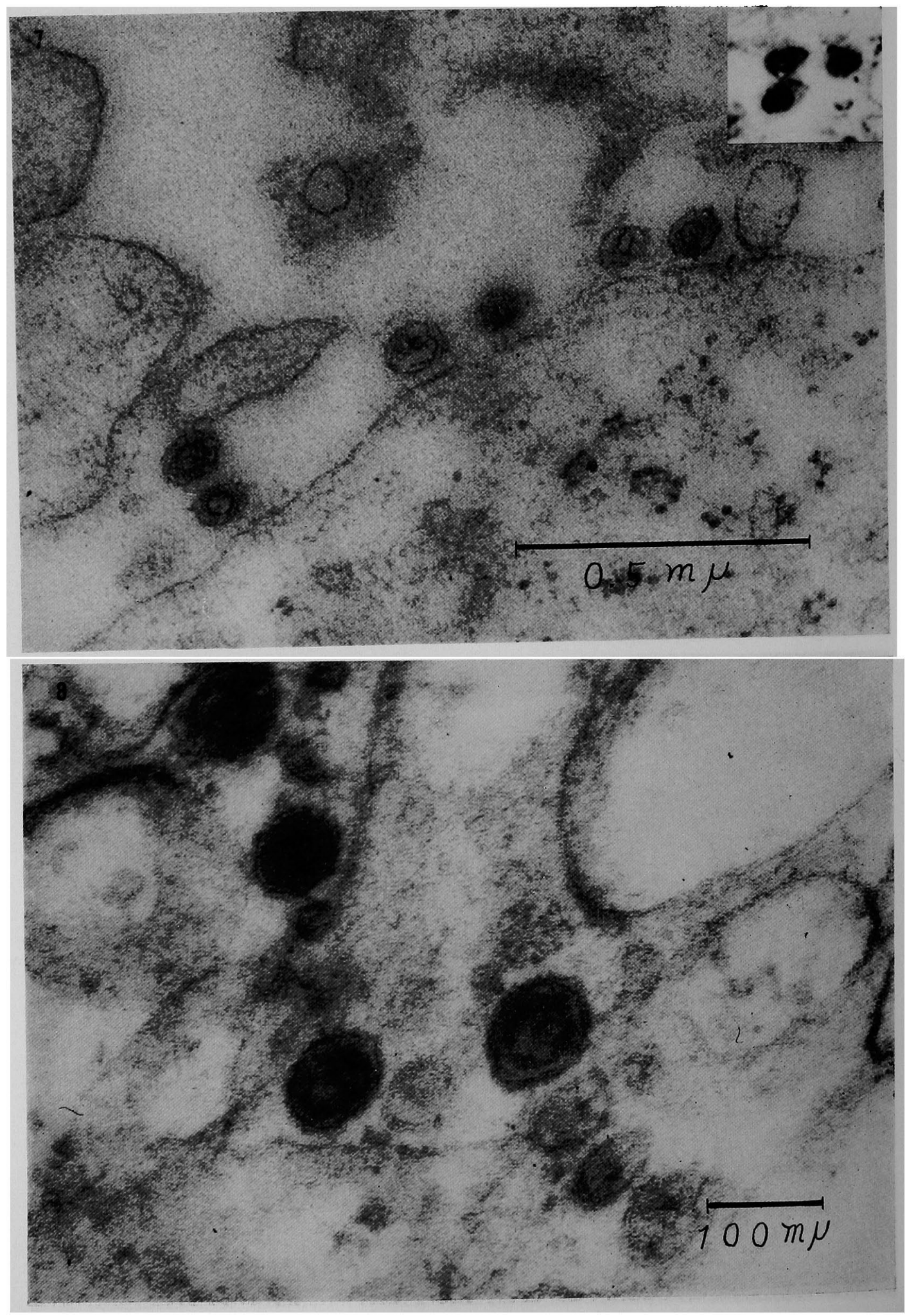
平木外13名論文附図
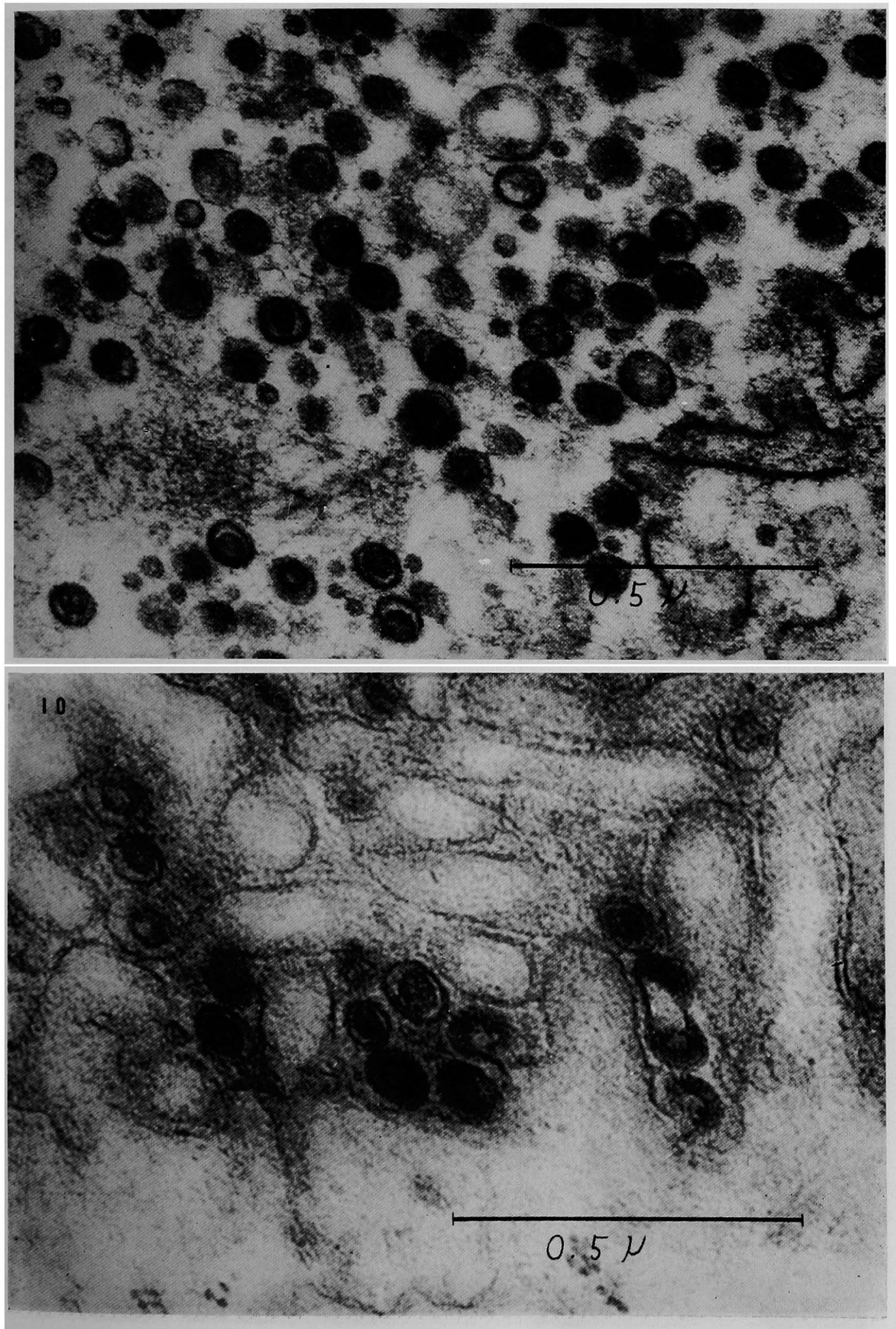
平木外 13 名論文附図
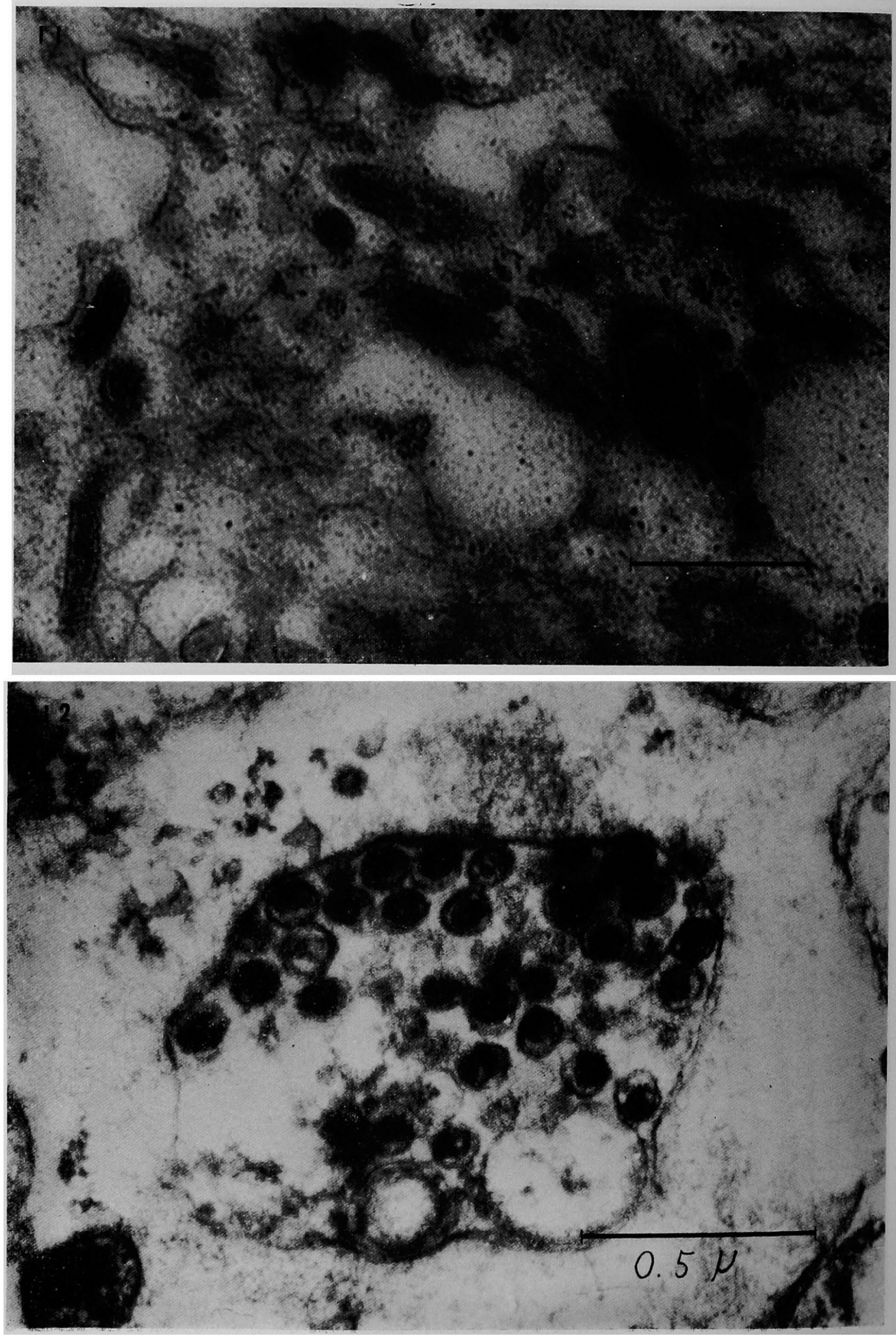
平木外 13 名論文附図
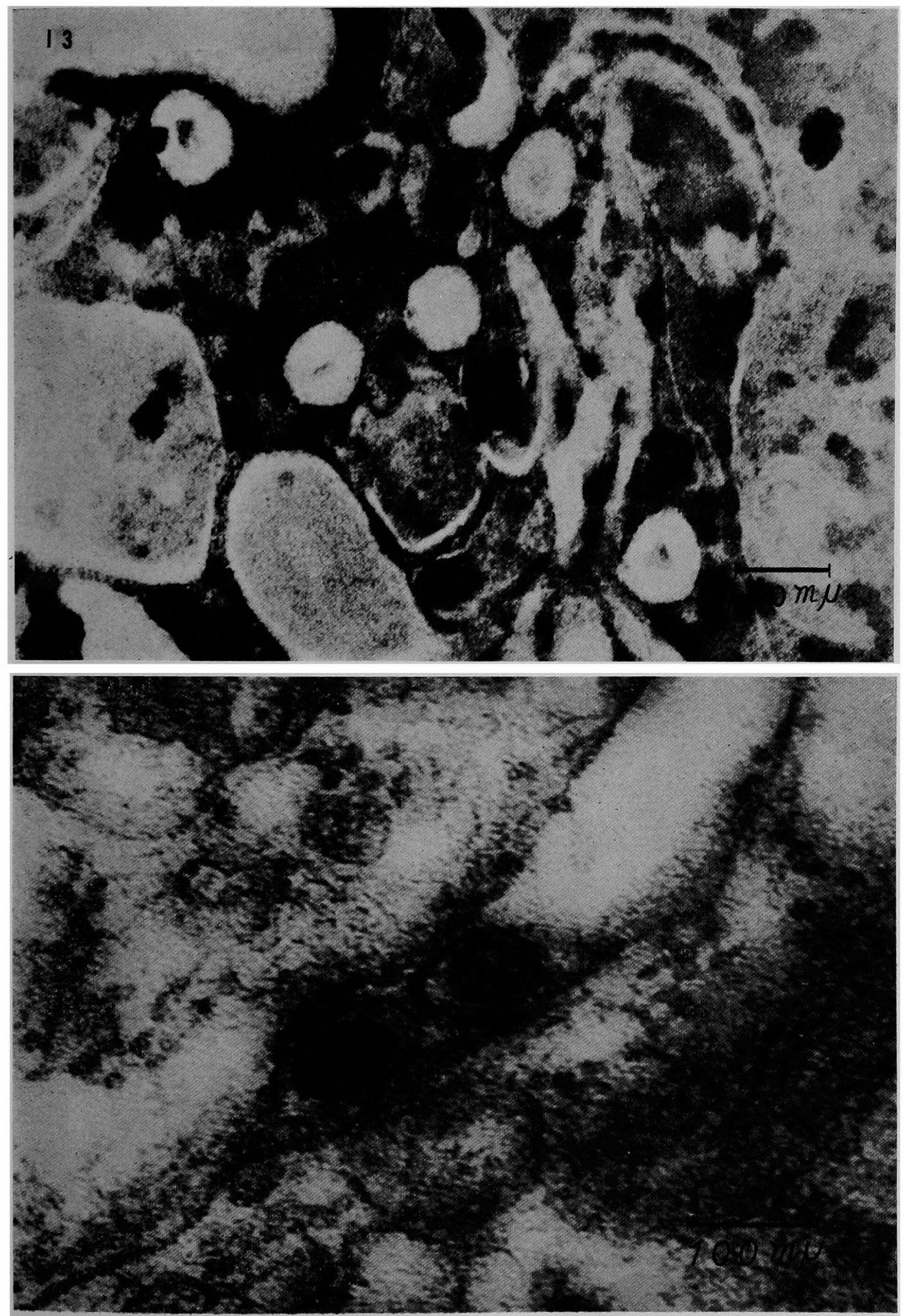
平木外13名論文附図
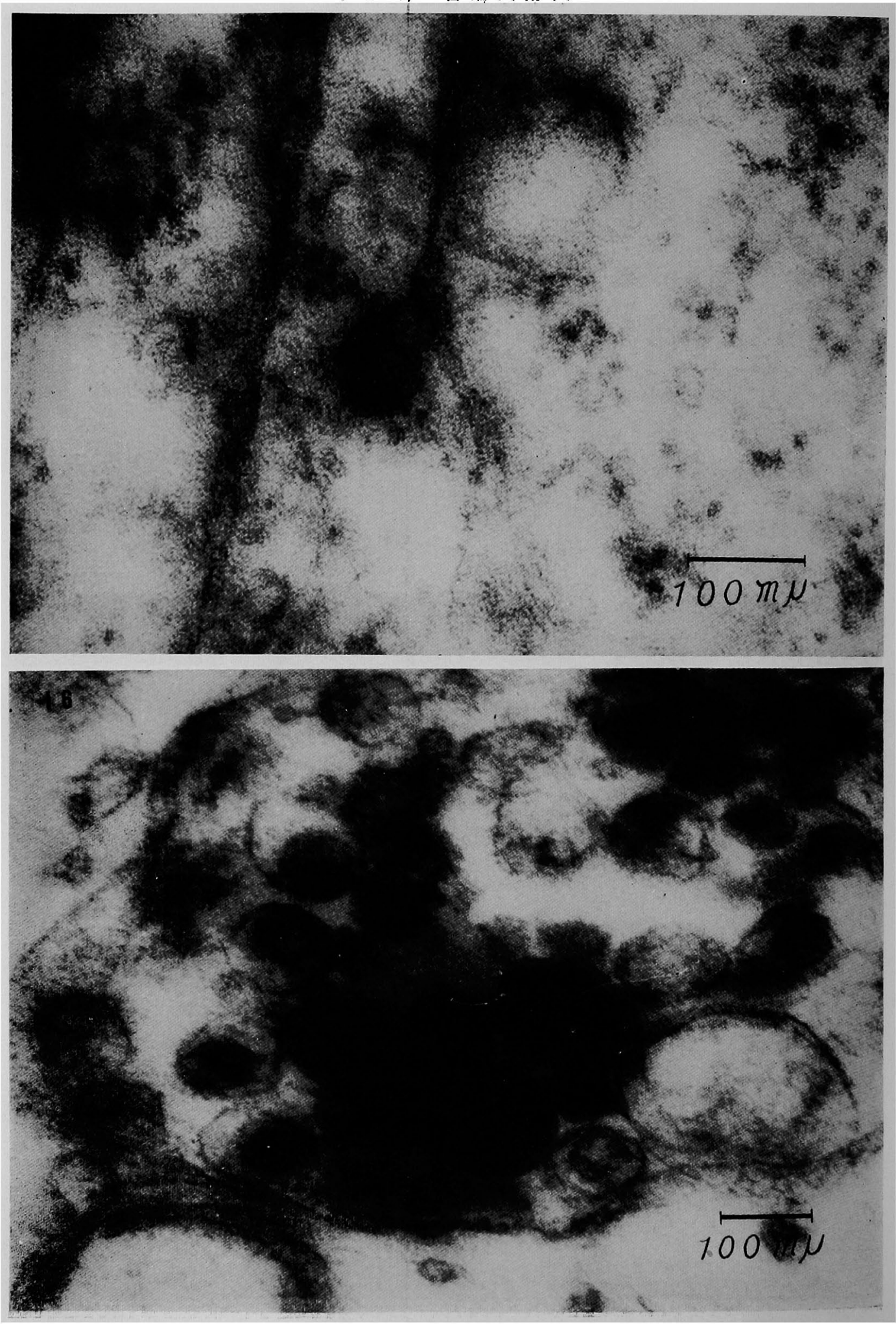
平木外13名論文附図

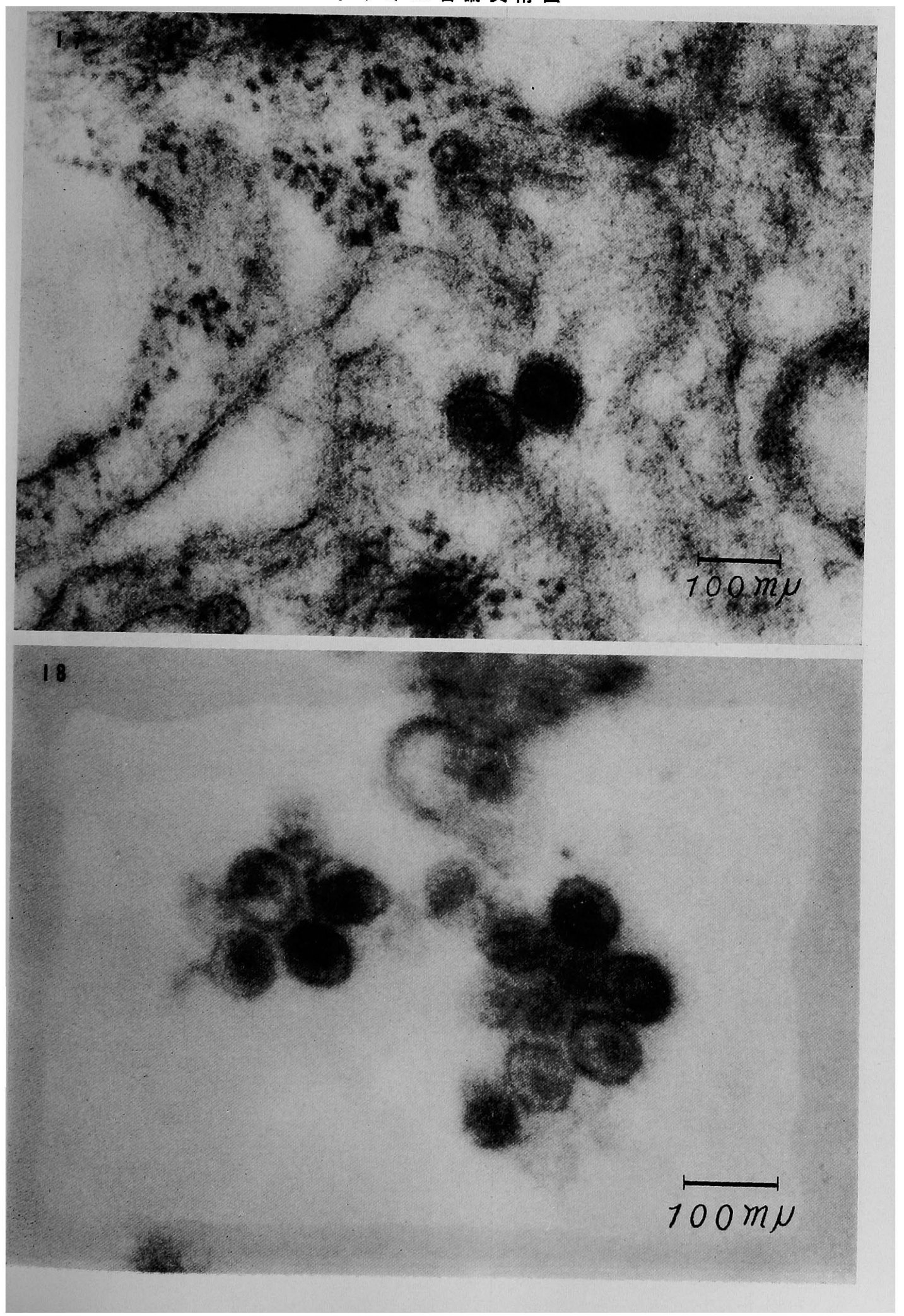




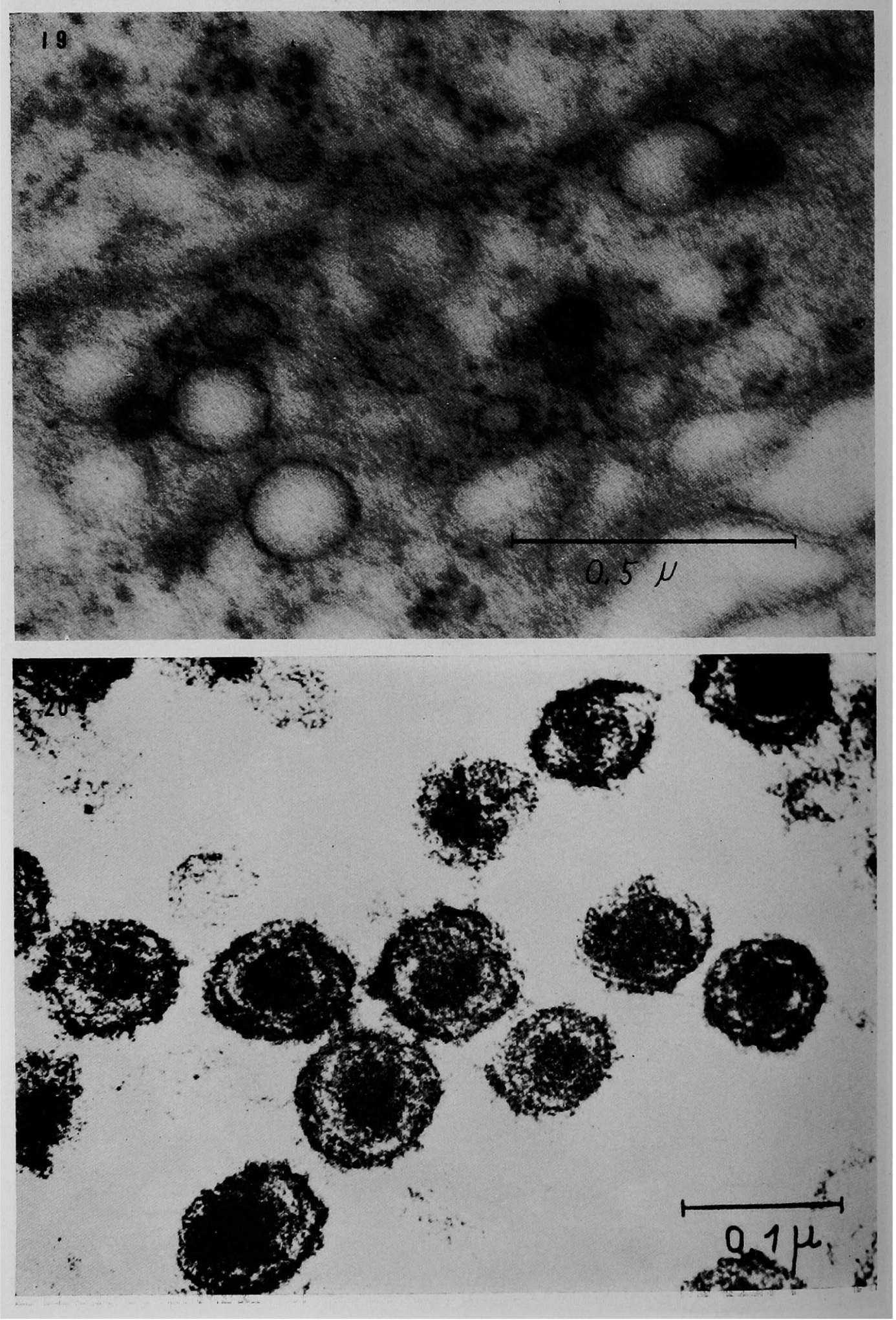


平木外 13 名論文附図
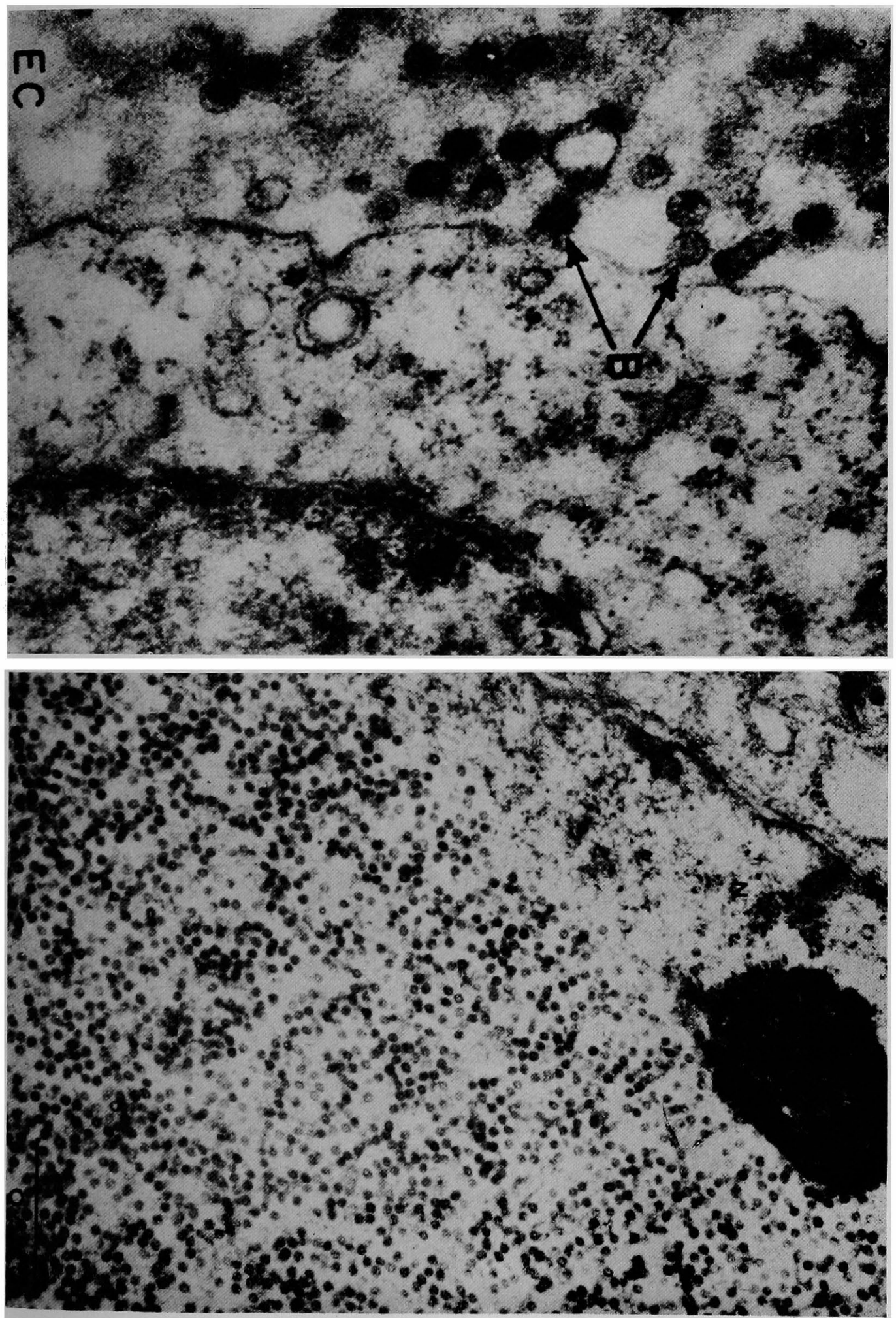


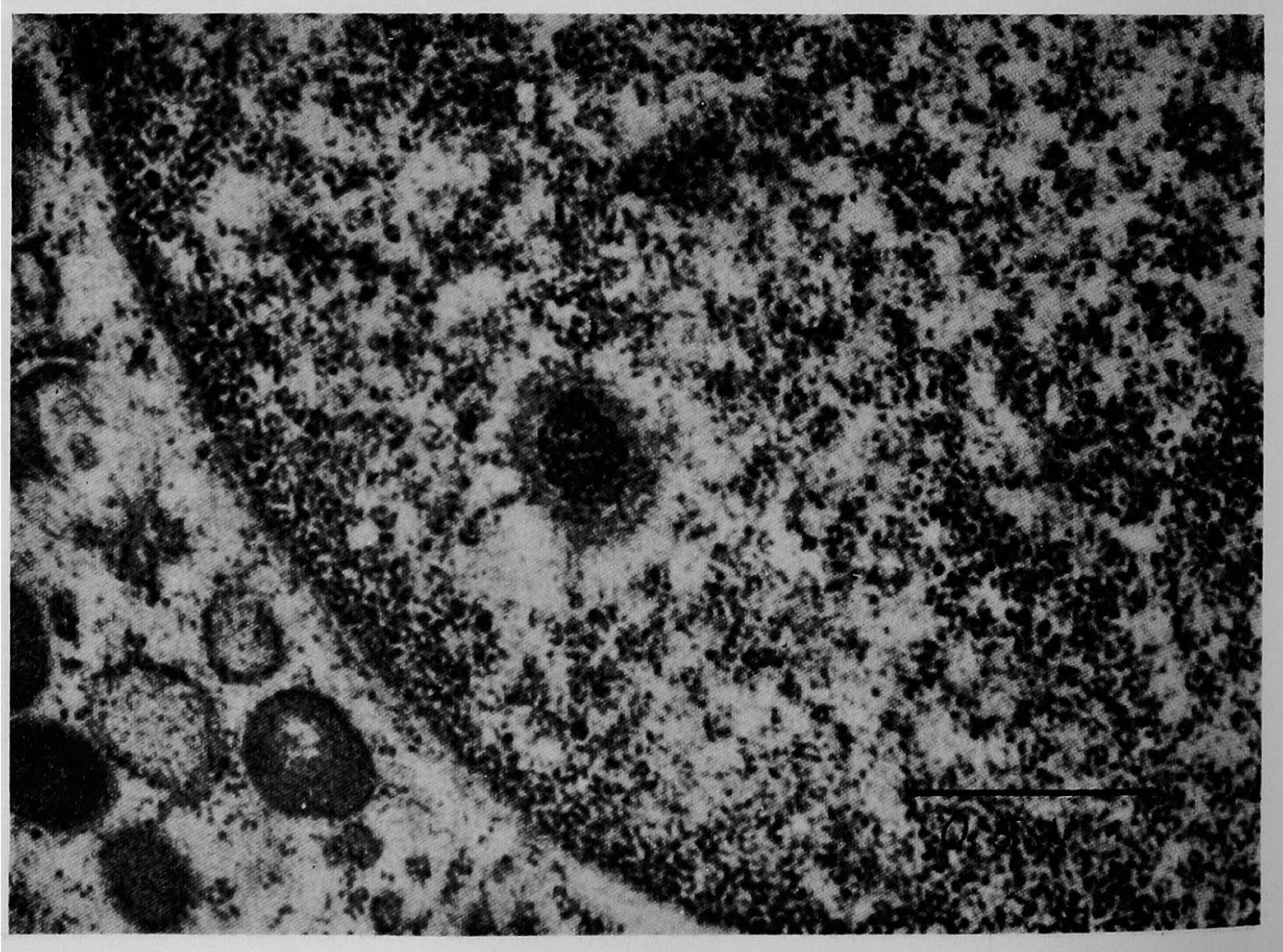


平木外 13 名論文附図

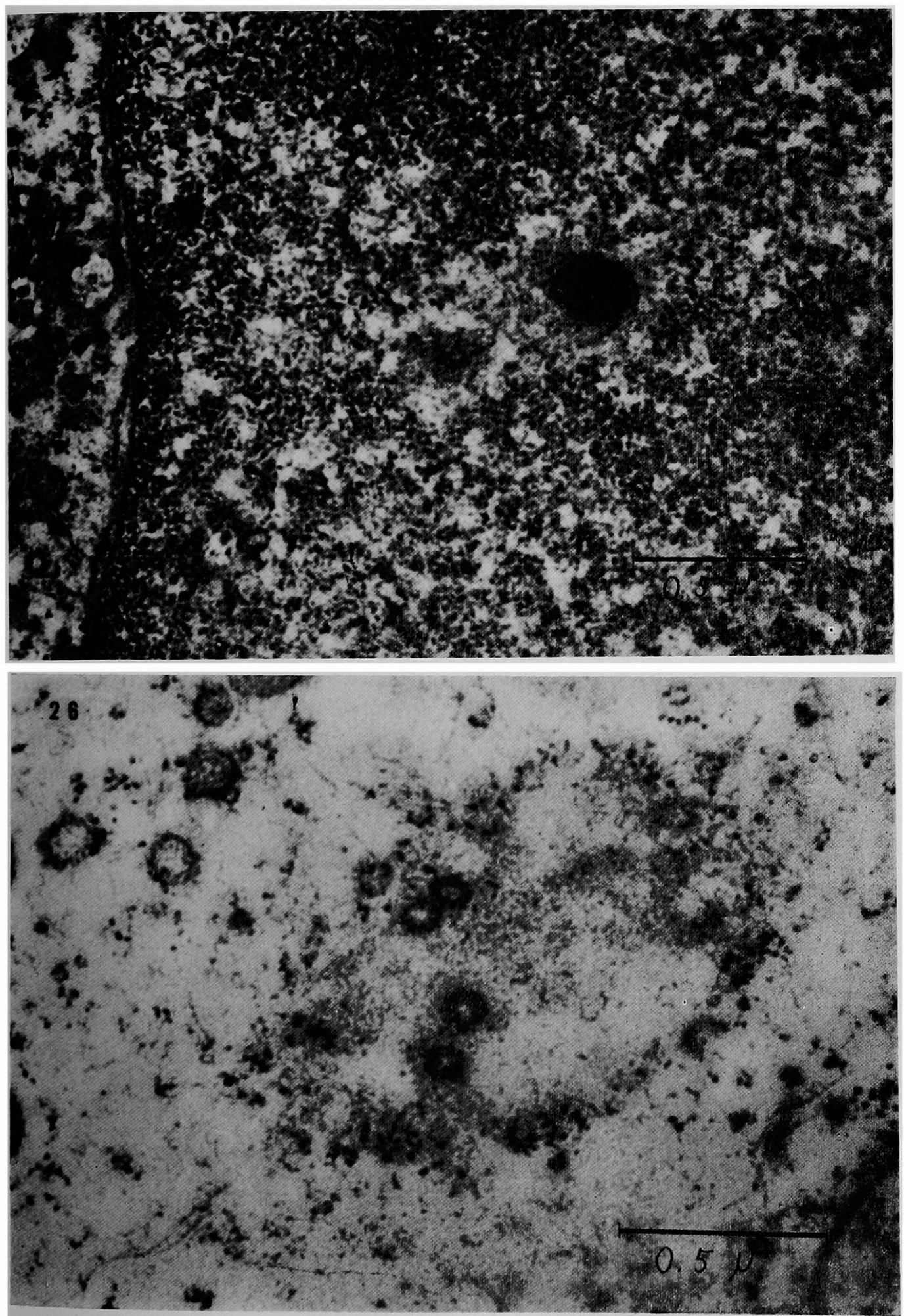

